\title{
Comparison of Carbon and Opal export rates between summer and spring bloom periods in the region of the Antarctic Polar Front, SE Atlantic
}

Michiel M. Rutgers van der Loeff ${ }^{1}$, Ken Buesseler ${ }^{2}$, Uli Bathmann ${ }^{1}$, Inga Hense ${ }^{1}$, John Andrews ${ }^{2}$

${ }_{1}^{1}$ Alfred Wegener Institute for Polar and Marine Research, PO Box 120161, D27515 Bremerhaven Germany

${ }^{2}$ Woods Hole Oceanographic Institution, Woods Hole, Mass 02543, USA

\begin{abstract}
Although primary production in the Antarctic Circumpolar Current is not above the world average and carbon burial rates are low, $70 \%$ of the world's opal burial occurs in this zone and it has been suggested that blooms of large diatoms are responsible for this extraordinary situation. Here we compare export fluxes during bloom and steadystate situations near the Antarctic Polar Front in the SE Atlantic.
\end{abstract}

In a previous expedition during the austral spring, we observed the development of a bloom that led to the sudden export of particles (Rutgers van der Loeff et al., 1997). Here we report the results of a second expedition to the same area in summer (DecJan), 3 years later. ${ }^{234} \mathrm{Th}$ was monitored in the surface water and in Rosette casts down to a water depth of $500 \mathrm{~m}$ as tracer of export production in an intensive sampling program within a box of $275 \times 375 \mathrm{~km}$.

The distribution of particulate and dissolved ${ }^{234} \mathrm{Th}$ was remarkably constant over time and location. Total (dissolved + particulate) ${ }^{234} \mathrm{Th}$ activities were depleted relative to its parent ${ }^{238} \mathrm{U}$ at the surface $\left({ }^{234} \mathrm{Th} / 238 \mathrm{U}\right.$ activity ratio approximately $\left.83 \%\right)$, reaching equilibrium at a depth of around $190 \mathrm{~m}$. This constant depletion corresponds to a ${ }^{234} \mathrm{Th}$ export rate of $1115 \mathrm{dpm} \mathrm{m}^{-2} \mathrm{~d}^{-1}, 35 \%$ of the value observed during the spring bloom.

Below $80 \mathrm{~m}$ depth, ${ }^{234} \mathrm{Th}$ on suspended particles is well correlated with both particulate organic carbon (POC) and particulate biogenic silica (BSi) with a 
POC/234 Th ratio of $10.2 \pm 0.8 \mu \mathrm{mol} / \mathrm{dpm}$ and a BSi $/ 234 \mathrm{Th}$ ratio of $2.9 \pm 0.2 \mu \mathrm{mol} / \mathrm{dpm}$. Using these ratios, the export from the upper $190 \mathrm{~m}$ can be calculated to be $11.3 \mathrm{mmol}$ $\mathrm{C} \mathrm{m}^{-2} \mathrm{~d}^{-1}$ and $3.2 \mathrm{mmol} \mathrm{Si} \mathrm{m}^{-2} \mathrm{~d}^{-1}$.The export rates from the surface mixed layer (at $100 \mathrm{~m}$ depth) are $8.8 \mathrm{mmol} \mathrm{C} \mathrm{m}^{-2} \mathrm{~d}^{-1}$ and $2.5 \mathrm{mmol} \mathrm{Si} \mathrm{m}^{-2} \mathrm{~d}^{-1}$.

Thus, whereas in spring we had observed a sudden increase from a negligible to a high export rate, the summer situation around the Polar Front was characterized by a lower but steady export rate. This summer flux contributes a similar fraction to the annual export budget as the previously observed spring bloom, which has higher export rates but a much shorter duration. 


\section{Introduction}

The Antarctic Circumpolar Current (ACC) constitutes a transition between High Nutrient Low Chlorophyll (HNLC) water in the south and the oligotrophic gyres in the north. The extent of nutrient utilization in Antarctic Surface Waters before these waters are subducted northwards as Antarctic Intermediate Water has a large impact on global nutrient and carbon cycles. The role of the ACC region as a sink for $\mathrm{CO}_{2}$, in glacial epochs (Sarmiento and Orr, 1991; Kumar et al., 1995) and in the future as sink for anthropogenic $\mathrm{CO}_{2}$, is much debated. A prerequisite for this discussion is an adequate description of the present carbon fluxes in this area.

The Southern Ocean plays a central role in the world's silica budget. $70 \%$ of the worldwide opal accumulation takes place in the so-called opal belt (Tréguer et al., 1995), a 5-10 degrees wide band from approximately the Polar Front southward (Lisitzin, 1972/1996). Biogenic silica production in the Southern Ocean is not particularly high (Tréguer and van Bennekom, 1991; Leynaert et al., 1993), although the estimate has been adjusted upward (Nelson et al. 1995) after the observation of high opal productivity related to diatom blooms near the Polar Front (Quéguiner et al., 1997). The reasons for the high preservation of opal in this zone, in contrast with the negligible preservation to the south in the Weddell Sea (Leynaert et al., 1993; Schlüter et al., 1998) is regarded as one of the key questions in the silica cycle (Nelson et al., 1995; Ragueneau et al., subm.), questions that remain even after recent adjustments of the estimates for production and burial rates (Pondaven et al., 2000). We do not yet know whether the answer has to be looked for in the surface mixed layer or in the deeper water column. Actual export fluxes are needed to tackle these questions.

Various authors have stressed the importance of blooms for the annual export fluxes from the euphotic zone in the Southern Ocean. The current hypothesis is, that a steady low export from a largely recycling small food web community is superimposed by diatom blooms (Smetacek et al., 1990), presumably initiated by iron pulses (De Baar et al., 1995; De Baar and Boyd, in press) and associated with large export fluxes (Buesseler, 1998). These arguments have primarily been developed for the carbon cycle, but as they are based on blooms of diatoms, they have also been applied to the fluxes of biogenic silica (e.g. Nelson et al., 1995). Recenty, however, it was shown both in natural upwelling conditions (Hutchins and Bruland, 1998) and in 
culture experiments (Takeda 1998), that iron fertilization affects $\mathrm{C}, \mathrm{N}$ and $\mathrm{P}$ uptake much more than Si uptake. Boyle (1998) hypothesized that diatoms growing under iron stress form heavily silicified frustules that sink out rapidly. According to this mechanism, a bloom triggered by an iron pulse would enhance the export flux of $\mathrm{C}$ more than of $\mathrm{Si}$.

The frequent occurrence of fluff on the sediment surface in the Permanently Open Ocean Zone (POOZ) south of the Polar Front (Riaux-Gobin et al., 1997) can be interpreted as an indication of pulsed sedimentation. Sediment trap deployments have indeed shown highly seasonal fluxes of organic carbon and opal in the Southern Ocean. In the Bransfield Stait, 95\% of the annual trap flux was collected in less than two summer months (Wefer et al., 1988, 1990). Krill fecal pellets constituted a large fraction of this flux, thus it was postulated that the annual flux is controlled by krill feeding on a diatom bloom. The trap flux in the central Weddell Sea was also highly seasonal, but ice conditions were postulated to be the major control in this area (Fischer et al., 1988). Near Maud Rise the seasonal variability of the trap flux was much smaller (Wefer et al., 1990), and near the Polar Front the fluxes were highly variable during the full summer season and negligible in the period mid April- mid October (Fischer and Wefer, unpubl.). Thus, sediment traps give both examples of stations where the annual flux is overwhelmed by a short and intense event, and stations which have a more steady flux during the summer months.

In order to prevent the risk of damage by icebergs and to minimize artefacts that have especially been observed in shallow trap deployments (Baker et al., 1988; Gust et al., 1994), the minimum deployment depth of these sediment traps was usually over $500 \mathrm{~m}$. Therefore, the trap data cannot give us the export rates from the euphotic zone, since a large part of organic matter is remineralized above this depth (e.g. Whitworth and Nowlin, 1987; Usbeck et al., in prep.) and even a large part of the BSi production may dissolve before reaching this depth (Leynaert et al., 1993).

In this paper we investigate whether actual export fluxes from the euphotic zone in the Southern Ocean are controlled by blooms. In a previous paper we used ${ }^{234} \mathrm{Th}$ to estimate the export of organic carbon from the euphotic zone during a spring bloom, in parallel to flux calculations based on measurements of the $\mathrm{CO}_{2}$ system (Bakker et al., 1997). Here we calculate opal export during that same bloom. We compare these 
export rates with the rates in a more steady summer situation, observed three years later in the same area around the Polar Front in the South East Atlantic.

\section{Methods}

\subsection{Sampling sites}

During Polarstern expedition Ant XIII/2 (Dec 1995-Jan 1996, Bathmann et al., 1997a) surface water samples were obtained from the ship's seawater supply during transects through the circumpolar current (Fig. 1). Two surface water transects were collected from Cape Town to the Polar Front (4: 4-9 Dec, 11: 19-23 Jan) and four transects from the Polar Front to the Antarctic continent at Neumayer Station (4: 9-15 Dec; 5: 19-23 Dec; 10: 7-12 Jan; 11: 14-18 Jan). In addition, 13 depth profiles were obtained with Rosette casts during an intensive monitoring program in a 275 x 375 $\mathrm{km}$ box around the Polar Front (23 Dec $-7 \mathrm{Jan}$ ) and one additional profile was obtained just south of the PF at $54^{\circ} \mathrm{S}$ (station 9, $22 \mathrm{Dec}$ ).

\subsection{Thorium-234 analyses}

${ }^{234} \mathrm{Th}$ analysis of the Rosette casts was done with a $\mathrm{MnO}_{2}$-coprecipitation technique described by Rutgers van der Loeff and Moore (1999). Briefly, 15-25L samples are filled into a graduated plexiglass cylinder. Volume is measured and the samples are filtered by air pressure from a membrane pump ( $<0.8 \mathrm{bar},<80 \mathrm{kPa})$ over a $142 \mathrm{~mm}$ diameter $1-\mu$ poresize nuclepore membrane. To a weighed aliquot of the filtrate (max. 20 Liter) are added 6 drops of concentrated ammonia (25 weight $\%$ of $\mathrm{NH}_{3}$ ) and 250 $\mu \mathrm{l}$ of concentrated $\mathrm{KMnO}_{4}$ solution $(60 \mathrm{~g} / \mathrm{L})$, followed after mixing by $100 \mu \mathrm{l}$ concentrated $\mathrm{MnCl}_{2}$ solution ( $400 \mathrm{~g} \mathrm{MnCl}_{2} \cdot 4 \mathrm{H}_{2} \mathrm{O} / \mathrm{L}$ ). The resulting $\mathrm{MnO}_{2}$ precipitate is allowed to form for 8 hours and filtered over a second 142-mm nuclepore filter. Both filters, containing the suspended particles and the $\mathrm{MnO}_{2}$ precipitate, respectively, are dried, folded and beta counted on board. A second beta counting after decay of ${ }^{234} \mathrm{Th}$ is required to correct for the contribution of other beta emitters than ${ }^{234} \mathrm{Th} / 234 \mathrm{mPa}$ (about $4 \%$ ). Beta absorption of loaded filters is quantified by counting a ${ }^{234} \mathrm{Th}$ source with and without the filter in-between. It was calculated that self absorption of filters containing the $\mathrm{MnO}_{2}$-precipitate or suspended particles from subsurface samples reduced their count rates by 25 and $19 \%$, respectively. Calibration was done with filters containing a ${ }^{238} \mathrm{U}$ spike with ${ }^{234} \mathrm{Th}$ in secular equilibrium, and was confirmed by measurements in the clear water minimum at 2000-2500m depth where ${ }^{234} \mathrm{Th}$ can be assumed to be in equilibrium with ${ }^{238} \mathrm{U}$ 
(Coale and Bruland 1987; Bacon and Rutgers van der Loeff, 1989; Rutgers van der Loeff and Berger, 1991). We estimate that the precision of the method for dissolved and particulate ${ }^{234} \mathrm{Th}$ is about $3 \%$, whereas the accuracy is about $5 \%$.

Surface water is taken in from the bow thruster tube at approx. $7 \mathrm{~m}$ depth, and supplied under pressure to the labs by a membrane pump with a capacity of around $30 \mathrm{~L} / \mathrm{min}$. ${ }^{234} \mathrm{Th}$ was analysed in parallel by two techniques. In addition to the $\mathrm{MnO}_{2}$ coprecipitation technique for discrete samples described above, we applied the Mn cartridge sampling procedure of Buesseler et al. (1992). Surface seawater was filtered over 142-mm glowed quartz filters, and the filtrate passed through two consecutive 7$\mathrm{cm}$ long $\mathrm{MnO}_{2}$-coated Hytrex cartridges. The cartridges were pressed and gamma counted after the cruise at Woods Hole according to Hartman and Buesseler (1994). We report only samples with cartridge collection efficiencies (determined from the activity ratio of the two cartridges) exceeding $60 \%$. An aliquot of the quartz filters was removed for $\mathrm{C} / \mathrm{N}$ analysis, the remainder was counted for beta activity. Given that these samples were collected while steaming, they represent average ${ }^{234} \mathrm{Th}$ activities over the approx. $20 \mathrm{~km}$ transect covered during sampling.

The distribution of particulate and dissolved ${ }^{234} \mathrm{Th}$ activity using the two techniques is clearly different. The continuous filtration of around 200L over quartz filters yields $50 \%$ higher values of particulate ${ }^{234} \mathrm{Th}$ than the filtration of $25-\mathrm{L}$ aliquots over nuclepore filters. We explain this discrepancy by adsorption of Th on the quartz filters (Buesseler et al., 1998). This process does not effect the concentrations of total (dissolved + particulate) activity, that were shown to compare well (see below). We note that continued adsorption during filtration may also play a role during nuclepore filtration, and this effect should be considered especially whenever Th data obtained with different techniques are to be compared.

\subsection{POC/PON and BSi analyses}

Care was taken that samples for particulate $\mathrm{C}$ and $\mathrm{N}$ analyses were collected simultaneously with discrete Th samples. In case of the continuous surface water sampling, the same quartz fiber filter was used for $\mathrm{C} / \mathrm{N}$ analysis and ${ }^{234} \mathrm{Th}$ beta counting. In case of the discrete thorium sampling, samples for POC and PON were collected from the same Rosette cast or simultaneously from the ship's seawater supply. One to two liters of water were filtered using precombusted $25 \mathrm{~mm} \mathrm{GF} / \mathrm{F}$ 
filters. Systematic studies on the effect of precombustion temperature of GF/F filters had shown that at $500^{\circ} \mathrm{C}$ not all carbon is combusted so that our "blanks" still contained a significant amount of "refractory" POC. Filters were combusted at $520^{\circ} \mathrm{C}$ for 12 hours. The filters were then stored frozen, fumed with $\mathrm{HCl}$ to remove inorganic carbonates, and analysed in a Perkin Elmer CHN analyser (Strickland and Parsons, 1972). POC and PON values were calculated after blank correction and calibration with acetanilide. Standard errors were 0.7 and $0.06 \mu \mathrm{mol} / \mathrm{L}$, respectively.

Recently, the small-volume filtration used here has been questioned because adsorption of DOC to the filters (Menzel 1966, Johnson and Wangersky 1985) may cause an overestimation of the POC concentration by an amount of about $2 \mu \mathrm{mol} / \mathrm{L}$ (Moran et al 1999). These latter authors ask for caution especially with small volume samples and POC levels below about $5 \mu \mathrm{mol} / \mathrm{L}$. Although nearly all values presented here from depths in excess of $80 \mathrm{~m}$ are below this threshold, there is no intercept in the plot of ${ }^{234}$ Th versus POC (Fig. 4a) or of Ap/Ad versus POC (Fig. 5a) which would point at such a blank problem. The absence of an intercept still does not exclude that a fraction of DOC with a similar depth dependence as POC is adsorbed on the filters. As the study of Moran et al. does not show a clear relation between the amount of DOC adsorbed and POC concentration or water depth, we interpret the absence of an intercept as an indication that the artefact is not significant in our study.

Samples for the determination of biogenic silica were taken from the same cast as POC and PON. Two litres were filtered on cellulose-acetate-filters, which were stored frozen. After the cruise at AWI the filters were incubated with $0.1 \mathrm{M} \mathrm{NaOH}$ for two hours in a water bath at $85^{\circ} \mathrm{C}$ and measured photometrically according to Mueller and Schneider (1993). The standard error was $0.017 \mu \mathrm{mol} / \mathrm{L}$.

\section{Results}

\subsection{Polar Front Box}

The two methods used to measure ${ }^{234} \mathrm{Th}$ in surface waters, in-line filtration (ILF) averaging over a transect of approximately $20 \mathrm{~km}$, and discrete-sample filtration (DF), yield comparable results for total Th (Table 1). All ILF data in the Polar Front Box average $0.81 \pm 0.08(n=15)$, indistinguishable from the value of $0.81 \pm 0.04(n=46)$ for all DF surface water data $(<=20 \mathrm{~m})$ from this area. At the four stations $(11,34,35,38)$ where the transect used for the in-line filtration (ILF) was next to a station with 
discrete data (DF), the total ${ }^{234} \mathrm{Th} / 238 \mathrm{U}$ ratios averaged 0.89 and 0.80 , respectively (Table 1). As the two sampling methods cannot be performed in the same water mass, the difference may be due to inhomogeneity. We conclude that there is no systematic difference between these two methods. Both independent data sets confirm that the surface water was depleted in ${ }^{234} \mathrm{Th}$ by $19 \pm 6 \%$ relative to its parent ${ }^{238} \mathrm{U}$ in the entire box and throughout the 46-days investigation period (6. Dec to 21. Jan).

\subsection{Vertical distribution}

All thirteen profiles from the Polar Front box are remarkably similar (Fig. 2). Particulate ${ }^{234} \mathrm{Th}$ has the highest activity in the upper $60 \mathrm{~m}$, and gradually declines downward, reflecting the distribution of suspended particles. Total ${ }^{234} \mathrm{Th}$, the sum of particulate and dissolved activities, is depleted relative to ${ }^{238} \mathrm{U}$ in the surface water by about $17 \%$. This depletion gradually disappears by $200 \mathrm{~m}$.

Station 9 lies south of the Polar Front box at $54^{\circ} \mathrm{S}$ (Fig. 1) and stands out in Figure 2 due to its low surface water ${ }^{234}$ Th activity. A SeaSoar survey on the southward transect 4 had shown at around $54^{\circ} \mathrm{S}$ a zone with a deep chlorophyl-a penetration with high values throughout to about $130 \mathrm{~m}$ and a high abundance of zooplankton in the depth range of 100-160m (Read et al., this issue). At that time, the depletion of total ${ }^{234} \mathrm{Th}$ relative to ${ }^{238} \mathrm{U}$ in the surface water was $35 \%$ (Fig. 3), indicative of a high export flux. The vertical distribution of ${ }^{234} \mathrm{Th}$ was only obtained when we returned here 12 days later (station 9, Fig. 2). The high chlorophyll levels in the upper 100m had disappeared by then, and the depletion of ${ }^{234} \mathrm{Th}$ in the surface water was only $23 \%$, not much higher than in the Polar Front box. However, the vertical distribution of ${ }^{234} \mathrm{Th}$ was different from all other stations. Particulate ${ }^{234} \mathrm{Th}$ in the upper $100 \mathrm{~m}$ was relatively low, and the depletion of total ${ }^{234} \mathrm{Th}$ was high down to at least $100 \mathrm{~m}$ depth, consistent with the recent sinking of a deep penetrating algal bloom.

Stations 16 and 20 display relatively high contents of total ${ }^{234} \mathrm{Th}$ in the 50 to $80 \mathrm{~m}$ depth range. These high activities might suggest upwelling of less depleted deeper waters, but this explanation is in conflict with the particulate ${ }^{234} \mathrm{Th}$ values that are among the highest measured at $50 \mathrm{~m}$ depth. It is more likely that these stations have received an additional particulate input. No evidence for such an input could be found however in the data sets of plankton parameters at these stations (Bathmann et al., 1997a). 


\subsection{Distribution of ${ }^{234}$ Th in surface waters during transects across the ACC}

In a wide latitude band within the ACC, from about $48^{\circ} \mathrm{S}$ to $58^{\circ} \mathrm{S}$, there was a moderate depletion on all transects of surface water total ${ }^{234} \mathrm{Th}$, with very little variation (Fig. 3). The strongest depletion occurred further north around the subtropical front. In the southernmost stations, dramatic changes occurred in samples that had been drawn when the ship was breaking its way through melting ice. These observations are discussed further below.

\section{DISCUSSION}

\subsection{Depletion of thorium-234 in Polar Front region during the austral summer}

The depletion in ${ }^{234} \mathrm{Th}$ relative to ${ }^{238} \mathrm{U}$ (Fig. 2) implies that particle export from the euphotic zone was very constant in time and space near the Polar Front during December - January. The Polar Frontal region is characterized by large physical variability over short distances due to the meandering of the front (Veth et al., 1997; Pollard et al., this issue), and eddy formation. During the present expedition, a field of upwelling and downwelling cells was observed (Strass et al. this issue) which was reflected in many biological parameters (Pollard et al., this issue). Given this variability we were somewhat surprised that the export flux should be so constant in time and space. Therefore, we need to explore below whether or not the constant and depleted ${ }^{234}$ Th activities might be a result of methodological error. The ${ }^{234}$ Th profiles are so similar that random errors can be excluded. But two systematic errors are possibly associated with the direct beta counting technique for ${ }^{234} \mathrm{Th}$ :

\subsection{1.contribution of radium daughters}

Our direct beta counting of $\mathrm{MnO}_{2}$ precipitate can include a contribution from other nuclides, the most likely being the radium decay products. We have followed the beta activity of the $\mathrm{MnO}_{2}$ filters over time and found that $3.8 \pm 1.0 \%$ of the activity remained after decay of ${ }^{234} \mathrm{Th}$. All ${ }^{234} \mathrm{Th}$ calculations have been corrected accordingly, but we must also check whether beta emissions of Ra daughters, which display strong acitivity gradients in the surface ocean, might have caused observed gradients in ${ }^{234} \mathrm{Th}$. The decay of ${ }^{226} \mathrm{Ra}$ produces ${ }^{214} \mathrm{~Pb}$ (maximum beta energy 1.02 $\mathrm{MeV}$ ) and ${ }^{214} \mathrm{Bi}(3.27 \mathrm{MeV})$, whereas ${ }^{210} \mathrm{~Pb}$ decays to ${ }^{210} \mathrm{Bi}(1.16 \mathrm{MeV}$; the beta decay of ${ }^{210} \mathrm{~Pb}$ itself is too weak). In order to check the contribution of these 
emissions to the observed beta count rate, we deposited ${ }^{226} \mathrm{Ra}$ and ${ }^{210} \mathrm{~Pb}$ spikes on filters with $\mathrm{MnO}_{2}$ precipitate. These filters were then counted and evaluated as ${ }^{234} \mathrm{Th}$ samples. The count rate of the ${ }^{226} \mathrm{Ra}$ and ${ }^{210} \mathrm{~Pb}$ daughters will depend upon possible losses of intermediate gaseous radon decay products, and the efficiency of detection for the $\mathrm{Pb}$ and $\mathrm{Bi}$ beta emitters. We find that the resulting count rates were equivalent to $10 \%$ of the original ${ }^{226} \mathrm{Ra}$ and $40 \%$ of the ${ }^{210} \mathrm{~Pb}$ activity and if present at high enough levels, could contribute to the observed count rates that we attribute solely to ${ }^{234} \mathrm{Th}$. In order to calculate whether this is a significant or variable artifact, we therefore need to consider in-situ ${ }^{226} \mathrm{Ra}$ and ${ }^{210} \mathrm{~Pb}$ activities.

${ }^{226} \mathrm{Ra}$ is well correlated with $\mathrm{Si}(\mathrm{Ku}$ and $\mathrm{Lin}, 1976)$, which displays a strong gradient in the surface water (Hense et al., this issue). The ${ }^{226} \mathrm{Ra}$ activity is estimated at 0.22 $\mathrm{dpm} / \mathrm{L}$ in deep waters decreasing to $0.08-0.13 \mathrm{dpm} / \mathrm{L}$ at silicate depletion. ${ }^{210} \mathrm{~Pb}$ displays a similar distribution with a maximum activity gradient of about $0.13 \mathrm{dpm} / \mathrm{L}$ at $200 \mathrm{~m}$ to $0.07 \mathrm{dpm} / \mathrm{L}$ at the surface (Friedrich, 1997). Assuming $100 \%$ efficient precipitation of Ra daughters with $\mathrm{MnO}_{2}$, these activities would thus cause a combined count rate equivalent to $0.074 \mathrm{dpm} / \mathrm{L}$ in deep water decreasing to 0.03 $\mathrm{dpm} / \mathrm{L}$ in surface waters. The difference is equivalent to $1.5 \%$ of $238 \mathrm{U}$, small compared to the observed depletion of $19 \%$. We thus conclude that depletions in ${ }^{226} \mathrm{Ra}$ and ${ }^{210} \mathrm{~Pb}$ in surface waters cannot account for the observed trend in our ${ }^{234} \mathrm{Th}$ profiles.

\subsubsection{Self absorption}

The only other factor that must be accounted for in our calibration for ${ }^{234} \mathrm{Th}$ is self absorption. Surface waters might have thicker filters and hence a higher self absorption of beta radiation. Without proper correction, the activity of surface samples with heavy particle load would become underestimated. However, we have quantified this self absorption and corrected for it (see Methods) and thus conclude again that the depletion in surface water ${ }^{234} \mathrm{Th}$ is real.

A final confirmation for the surface depletion in ${ }^{234} \mathrm{Th}$ comes from the independent determinations of ${ }^{234} \mathrm{Th}$ with continuous in-line filtration of surface waters and gamma counting method used by the WHOI lab. This provides a completely independent calibration that also strongly supports the existence of a depletion in ${ }^{234} \mathrm{Th}$ in surface waters (Table 1). All of these arguments allow us to conclude that the depletion is real. 


\subsection{Calculation of ${ }^{234}$ Th fluxes}

Since the ${ }^{234} \mathrm{Th}$ profiles do not change with time or location, we can apply a steady state scavenging model yielding the very simple formula for the export flux P:

$\mathrm{P}=\left(\mathrm{AU}-\mathrm{A}^{\mathrm{t}} \mathrm{Th}\right) * \lambda$

where $A_{U}$ is the activity of parent ${ }^{238} \mathrm{U}, \mathrm{A}^{\mathrm{t}} \mathrm{Th}$ the total activity of ${ }^{234} \mathrm{Th}$, and $\lambda$ the decay constant $\left(=0.0288\right.$ day $\left.^{-1}\right)$. With a depletion of $17 \%$ (19\% average for all surface values, Table 1) at the surface decreasing linearly to 0 at $190 \mathrm{~m}$ (fig. 2) we estimate a ${ }^{234} \mathrm{Th}$ deficit of $3.86(4.3) \mathrm{dpm} \mathrm{cm}^{-2}$, which corresponds to a steady state export rate of 1115 (1240) $\mathrm{dpm} \mathrm{m}^{-2} \mathrm{~d}^{-1}$ at $200 \mathrm{~m}$. The ${ }^{234} \mathrm{Th}$ deficit in the upper $100 \mathrm{~m}$ (the maximum depth of the surface mixed layer, Strass et al., this issue; Bathmann et al., 1997) amounts to $3.0 \mathrm{dpm} \mathrm{cm}^{-2}$, which corresponds to an export rate of $865 \mathrm{dpm} \mathrm{m}^{-2}$ $\mathrm{d}^{-1}$ at $100 \mathrm{~m}$

\subsection{Summer export of organic carbon and biogenic silica}

The export of ${ }^{234} \mathrm{Th}$ out of the surface layer must occur on sinking particles. In order to estimate the export of other components like organic carbon or biogenic silica, we have to know the ratio of these components to particulate ${ }^{234} \mathrm{Th}$ on the sinking particles.

It would be ideal if we could collect these sinking particles with traps, and in fact we deployed traps at 500m and 1500m depth for 21 days at one station (St 13, sampling intervals 48 hours). Unfortunately, sample sizes were not sufficient for on-board ${ }^{234} \mathrm{Th}$ analysis. Moreover, the efficiency of traps in collecting the absolute (Baker et al., 1988; Buesseler, 1991; Gust et al., 1994, Scholten et al., 2000, Yu et al., 2000) and also the relative (Buesseler et al., 2000) components of the vertical particle flux has been questioned, especially for sediment traps deployed at shallow depth. We therefore use as an alternative particulate samples collected via filtration, rather than sediment traps, and use these ratios to derive POC and BSi fluxes (see discussion below). 


\subsubsection{POC/Th and POC/BSi ratios}

Plots of particulate ${ }^{234} \mathrm{Th}$ versus POC (Fig. 4a) and BSi (Fig. 4b) from the Polar Front area show a good correlation within two distinct depth bands, with samples from below the surface mixed layer (depth $>=80 \mathrm{~m}$ ) having distinctly lower POC/Th and $\mathrm{BSi} / \mathrm{Th}$ ratios than samples at shallower depths and in surface waters. This decrease in $\mathrm{POC} / \mathrm{Th}$ ratios with depth has been observed in many previous studies (Murray et al., 1989, Buesseler et al., 1992; Buesseler et al., 1995, Rutgers van der Loeff et al., 1997, Buesseler et al., 2000). For example, in the Equatorial Pacific, Buesseler et al. (1995) see a decrease by a factor of two between the surface and $100 \mathrm{~m}$, similar to our results here. Higher POC/Th and $\mathrm{BSi} / \mathrm{Th}$ ratios in surface than in subsurface waters may have various causes:

A- In surface waters, the enhanced particulate load results in reduced concentrations of dissolved ${ }^{234}$ Th compared to the deep water. Particles settling out of the surface water come into contact with water masses with a higher dissolved activity, which must give rise to additional adsorption. The particulate ${ }^{234} \mathrm{Th}$ concentrations at intermediate suspended loads can be explained by this additional adsorption (A in Fig. 4). As long as $K_{d}$ remains constant, the ${ }^{234} \mathrm{Th}_{\text {part }} /{ }^{234} \mathrm{Th}_{\text {diss }}\left(\mathrm{A}^{\mathrm{p}} / \mathrm{A}^{\mathrm{d}}\right)$ ratio should decrease linearly with decreasing suspended load. Our deep and surface values of $\left(\mathrm{A}^{\mathrm{p}} / \mathrm{A}^{\mathrm{d}}\right)$ plotted against BSi and POC (Fig. 5) are indeed much closer to a single regression line. This implies, that the depth dependence of $\mathrm{POC} / \mathrm{Th}$ and $\mathrm{BSi} / \mathrm{Th}$ ratios on particles (Fig. 4) can to a large extent be explained by the measured reduced dissolved activities in surface waters. It should be noted, that in a bloom situation the change in dissolved activities was not a sufficient explanation for the change in POC/Th slope (Rutgers van der Loeff et al., 1997).

B- If adsorption onto filterable particles is controlled by aggregation of colloidal-sized particles, $\mathrm{K}_{\mathrm{d}}$ actually decreases with increasing particle load through the so-called particle concentration effect (Honeyman and Santschi, 1989). $K_{d}$ may also change with depth through a change in particle type and consequently in particle affinity for Th with depth (e.g. Lee et al., 1993). Such effects do not explain our observations as the relatively constant $\mathrm{POC} / \mathrm{A}^{\mathrm{p}} / \mathrm{A}^{\mathrm{d}}$ and $\mathrm{BSi} / \mathrm{A}^{\mathrm{p}} / \mathrm{A}^{\mathrm{d}}$ ratios in Figs. 5a and $5 \mathrm{~b}$ imply that the $\mathrm{K}_{\mathrm{d}}$ for Th adsorption was not very different in surface and subsurface waters. C- surface waters contain higher abundances of large phytoplankton and zooplankton (copepods, euphasids), with a low surface-to-volume ratio and a correspondingly high expected carbon to ${ }^{234} \mathrm{Th}$ ratio. They are caught on the filters but do not passively sink 
out below the euphotic zone, and their relative abundance in "suspended particulate material" is far higher in surface waters. The nonlinearity in Fig. 5 and the large scatter in surface waters compared to subsurface waters (Figs 4 and 5) may well be related to the abundance of zooplankton in surface waters. Our sampling methods do not collect the larger zooplankton.

D- Decomposition of organic carbon $\left(\mathrm{C}_{\text {org }}\right)$ and dissolution of opal in and below the surface mixed layer remove part of the primary produced $\mathrm{C}$ and $\mathrm{Si}$, whereas ${ }^{234} \mathrm{Th}$ continues to be produced from ${ }^{238} \mathrm{U}$ and to be available for adsorption at any depth. In other words: the residence time in the surface mixed layer of $\mathrm{C}_{\text {org }}$ is larger than of ${ }^{234}$ Th (Murray et al., 1989). The extent of decomposition of C and Si cannot be derived from these graphs, but will be discussed below in the context of the budget considerations.

The good correlation between POC, BSi and particulate ${ }^{234} \mathrm{Th}$ (Fig. 4) allows us to derive the $\mathrm{POC} / \mathrm{Th}$ and $\mathrm{BSi} / \mathrm{Th}$ ratio valid for the material suspended below $80 \mathrm{~m}$ depth, $\underline{\text { i.e. }}$ at the depth where the actual export from the surface mixed layer occurs. In our calculation of the export flux of POC and BSi we will assume that the particles settling out of the surface mixed layer (at approx. 100m) or out of the layer with measurable ${ }^{234} \mathrm{Th}$ depletion (at about $190 \mathrm{~m}$ ) have the same POC/Th and BSi/Th ratios as the particles suspended in this depth range $(80-500 \mathrm{~m})$. This assumption is questionable when the sedimentation is controlled by large particles and aggregates. These may or may not have a POC/Th ratio that is different from the deep suspended material (see compilation of data in Burd et al., 2000). Size-fractionated measurements using nitex screens have shown that large particles can have lower $\mathrm{POC} / \mathrm{Th}$ ratios than small particles, conceivably as a result of carbon respiration by grazers in the process of particle aggregation (Buesseler et al., 1995). However, a recent study in the Arabian Sea found higher POC/Th ratios on large particles (Buesseler et al., 1998). In this case a bloom of large diatoms may be responsible for the higher ratios on the $>53 \mu \mathrm{m}$ filters, if the POC/Th ratio is controlled by the decreased surface to volume ratios on large vs. small particles. In the Polar Front region along $170 \mathrm{~W}$, there is only a 5-30\% difference between the POC/Th ratio on particles $>70 \mathrm{um}$, and those >1-70um (Buesseler et al., 2000).

Only few studies allow a comparison of POC/Th ratios in trap material and in material suspended at the same depth. Buesseler et al. (1992) report 2-4 times lower ratios in trap material than in small particles suspended at the same depth at the NABE site, 
and ascribe this effect ( $c f$. Buesseler et al 1995) to the low POC/Th ratio on large particles, which may be collected with relatively good efficiency by sediment traps. In sediment trap material collected at 40m depth in the Baltic, Andersson et al. (2000) observed a POC/Th ratio that was an order of magnitude lower than in material suspended in the surface water, a difference too large to be explained by a possible gradient in suspended $\mathrm{POC} / \mathrm{Th}$ ratio between the surface and $40 \mathrm{~m}$ depth. At $150 \mathrm{~m}$ depth off Bermuda however, trap POC/Th ratios are equal to, or at times greater than the same ratio on GFF filters (Buesseler, unpublished data). In the equatorial Pacific, Murray et al. (1996) reported a factor of 2 higher POC/Th ratio in their (free-floating) traps than were found in $>53 \mu \mathrm{m}$ filtered samples. Such a relationship could be formed if fresh aggregates, with $\mathrm{POC} / \mathrm{Th}$ and $\mathrm{BSi} / \mathrm{Th}$ ratios derived from the surface layer, were to bypass the gradual decomposition and/or additional Th adsorption by their high settling rates. This range of observed relationships implies that export rates of $\mathrm{C}$ and Si based on suspended matter may well be a factor of two high or low. At present we have no way to constrain the results within these limits.

Ignoring one sample from the nepheloid layer (BNL) at station 18 with anomalously low POC/BSi ratio (Fig. 4), the regressions for all samples from the Polar Front area of $80 \mathrm{~m}$ and deeper, forced through the origin, are:

$\operatorname{POC}(\mu \mathrm{mol} / \mathrm{L})=10.2 \pm 0.8 *$ part.Th-234 $(\mathrm{dpm} / \mathrm{L})\left(\mathrm{r}^{2}=0.92, \mathrm{n}=51\right)$

$\mathrm{SiB}(\mu \mathrm{mol} / \mathrm{L})=2.9 \pm 0.2 *$ part.Th-234(dpm/L) $\left(\mathrm{r}^{2}=0.94, \mathrm{n}=47\right)$

Using these relationships, one can calculate the export of POC and BSi by multiplying the calculated ${ }^{234}$ Th flux, by the POC/Th and BSi/Th ratio derived from these regressions. Using this approach, the export of particulate organic carbon out of the upper $100 \mathrm{~m}$ layer is calculated to be $8.8 \mathrm{mmol} \mathrm{m}^{-2} \mathrm{~d}^{-1}$, whereas the export from the upper $200 \mathrm{~m}$ layer is $11.3 \mathrm{mmol} \mathrm{m}^{-2} \mathrm{~d}^{-1}$. For biogenic silica the export rates from the upper 100-m and 200-m layer amount to 2.5 and $3.2 \mathrm{mmol} \mathrm{m}^{-2} \mathrm{~d}^{-1}$, respectively (Table 2; average fluxes for Polar Front box during this summer cruise).

\subsection{Export of carbon and silica during a spring bloom}

In our 1992 study on particulate export near the Antarctic Polar Front (Rutgers van der Loeff et al., 1997) we witnessed the formation of an austral spring bloom. In a first period the phytoplankton standing stock increased to high levels but did not cause 
appreciable export. Only in a second 22-day period was a large particle export observed through the formation of a ${ }^{234} \mathrm{Th}$ deficit. Chlorophyll-a levels were still high at the end of our study, and it is possible that the export continued after we left the area. But in our estimation of the total export of carbon and silica related to the spring bloom we assume here that the bloom-related export was completed after this second period.

In our spring study we had observed a decrease of $\mathrm{POC} / 234 \mathrm{Th}$ ratio with depth using the same filtration methods as used in the present study (i.e. GFF for POC and $1 \mu \mathrm{m}$ nucleopore for ${ }^{234} \mathrm{Th}$ ). At the Polar Front, this POC/Th value was $20.9 \pm 3.1$ $\mu \mathrm{mol} / \mathrm{dpm}$ at $100 \mathrm{~m}$. We argued at that time that sinking particles would have a $\mathrm{POC} / \mathrm{Th}$ ratio on average that was 30-60\% of the surface water POC/Th ratio, and hence used as a POC/Th value of 6-12 in our calculations, reporting the value of 21 as an upper limit. Based upon evidence presented above, we do not feel confident making this correction here. In any case, we prefer to use the same methods to compare spring and summer export fluxes, hence for both studies use the observed $\mathrm{POC} / \mathrm{Th}$ value on filters at the depth of export. Using a POC/Th ratio of 21 $\mu \mathrm{mol} / \mathrm{dpm}$ and our calculated non-steady state ${ }^{234} \mathrm{Th}$ flux of $3200 \mathrm{dpm} \mathrm{m}^{-2} \mathrm{~d}^{-1}$ during the 22-day period between the sampling transects (Rutgers van der Loeff et al., 1997), we calculate at $200 \mathrm{~m}$ a POC flux of $67 \mathrm{mmol} \mathrm{m}^{-2} \mathrm{~d}^{-1}$ or $1.47 \mathrm{~mol} \mathrm{C}$ for the spring bloom period.

We base our estimate of the spring bloom opal export on a correlation of our particulate ${ }^{234}$ Th data (Rutgers van der Loeff et al., 1997) with BSi data of Quéguiner (Quéguiner et al., 1997 and personal communication). The BSi/234Th ratio was about $7.7 \mu \mathrm{mol} / \mathrm{dpm}\left(\mathrm{r}^{2}=0.7, \mathrm{n}=68\right)$, resulting in an export of $0.54 \mathrm{~mol} \mathrm{BSi} \mathrm{m}^{-2}$. The correlation is not as good as in the summer study (eq. 2), which may in part be due to the sampling strategy and heterogeneity in the surface waters, as ${ }^{234} \mathrm{Th}$ and BSi data were obtained from different CTD casts during the 1992 expedition. Another estimate of opal efflux, based on the export rates of both ${ }^{210} \mathrm{Po}$ and ${ }^{234} \mathrm{Th}$ to account for the differential settling rates of biogenic silica and POC, will be presented elsewhere (Friedrich et al., submitted). 


\subsection{A budget of $C_{\text {org }}$ and BSi fluxes near the PF; comparison with literature}

\subsection{1. primary production}

The $\mathrm{C}_{\text {org }}$ and $\mathrm{BSi}$ fluxes calculated above can be compared with available data on primary production and on fluxes in the water column and in the sediment for this ocean area. The available data have been summarized in Table 2 and Fig. 6. Although primary production is not particularly high in the Southern Ocean, the region influenced by the meanders of the Polar Front (PFr, Veth et al., 1997) has a high productivity with a large production rate of biogenic opal. Jochem et al. (1995) measured size-fractionated primary production whereas Quéguiner et al. (1997) measured carbon and silicon primary production during the same spring bloom described in our study (Polarstern Expedition ANT X/6). The data produced by these two teams for total carbon production during spring were similar. Using additional literature data Quéguiner et al. $(1996,1997)$ estimated a regional average annual production of biogenic silica in the SE Atlantic sector of $1600 \mathrm{mmol} \mathrm{m}^{-2} \mathrm{yr}^{-1}$ for the Polar Frontal Zone (PFZ) and PFr with a Si/C molar ratio of 0.3.

\subsection{2.sediment traps}

Two year-round sediment trap deployments have been made at the approximate position of the Polar Front: PF1 (50 ${ }^{\circ} 9.0^{\prime} \mathrm{S}, 5^{\circ} 46.4^{\prime} \mathrm{E}$, Wefer and Fischer, 1991) with a trap at $700 \mathrm{~m}$, and PF3 (50 $7.6^{\prime} \mathrm{S}, 5^{\circ} 50^{\prime} \mathrm{E}$, Fischer and Wefer, unpubl.) with traps at 614 and 3196m. The flux is variable in the period October-March with flux excursions in December, January and March, and very low in the period April to September (Fischer and Wefer, unpubl., Walter et al., 2000b). The bloom periods January and March are responsible for $34 \%$ and $37 \%$ of the annual carbon and opal flux, respectively, during the PF3 deployment (Table 2).

Trapping efficiencies, based on measured annual ${ }^{230} \mathrm{Th}$ fluxes, were $39 \%$ for PF1, and $67 \%$ and $47 \%$ for the shallow and deep traps for deployment PF3, respectively (Walter et al., 2000b). Flux calculations, based on the data on organic carbon and opal composition of Wefer and Fischer, 1991 and Fischer and Wefer, unpubl., and corrected for trapping efficiency, show that about $10 \%$ of carbon and $40 \%$ of opal primary production arrives at a depth of $700 \mathrm{~m}$ (Table 2). The sediment trap fluxes appear to be relatively low for opal. This may be due to some dissolution in the bottles, or to an error in the ${ }^{230} \mathrm{Th}$-based correction for undertrapping. As the area 
where the traps were deployed is influenced by outflow of Weddell Sea water, the export of ${ }^{230} \mathrm{Th}$ from the Weddell Sea gives rise to a flux of ${ }^{230} \mathrm{Th}$ in excess of its production in the water column, thus biasing the normalization method (Walter et al., 2000a). The actual trapping efficiency would then be even lower, suggesting an influence of currents in the Frontal Jet down to depths over 1000m where trap collection efficiency is usually better (Scholten et al., 1999 ; Yu et al., 2000). The carbon flux in the deep trap of PF3, however, is unusually high. A strong export event in March contributed 25\% of the annual flux but cannot explain the discrepancy between measured trap fluxes on one side and the fluxes from sediment measurements and the distribution of nutrients (inverse modelling) on the other.

\subsection{3. sediment accumulation}

The supply of opal and organic carbon to the seafloor can be calculated as the sum of the accumulation rate in the sediments and the decomposition rate in the surface sediments, deduced from pore water gradients of dissolved silicate and oxygen. Van Bennekom et al. (1988, and pers. comm.) arrived for the opal dissolution rate in surface sediments of the area of the Polar Front at an estimate of $350-600 \mathrm{mmol} \mathrm{m}^{-2}$ $\mathrm{yr}^{-1}$. Based on an extended data set Schlüter et al. (1998) found a median value of 600 mmol m${ }^{-2} \mathrm{yr}^{-1}$, equivalent to $38 \%$ of primary production (Table 2 ). The opal dissolution rates reported by Rabouille et al. (1997) near the Polar Front in the Indian Ocean $\left(57-58^{\circ} \mathrm{E}, 48-50^{\circ} \mathrm{S}\right)$ are in the same range $\left(590-950 \mathrm{mmol} \mathrm{m}^{-2} \mathrm{yr}^{-1}\right)$. The decomposition rate of organic carbon in the SE Atlantic was similarly estimated by Schlüter et al. (submitted) from the gradients of dissolved oxygen across the sedimentwater interface, and amounts to $2.4 \%$ of carbon primary production (Table 2).

The opal accumulation rate in the eastern Atlantic sector of the ACC, based on burial rates in dated sediment cores, amounts to a median value of $92 \mathrm{mmol} \mathrm{m}^{-2} \mathrm{yr}^{-1}$ (Schlüter et al., 1998). Analyses of ${ }^{230}$ Th have, however, shown that many sediment cores in the ACC are influenced by strong lateral sediment supply, the so-called sediment focussing (Francois et al., 1993; Frank, 1996, Frank et al., 1999, Pondaven et al., 2000). Using the constant flux model of Bacon (1984) the present focussingcorrected opal accumulation rate can be derived from core top data of biogenic opal content (from Schlüter, pers. comm) and excess ${ }^{230}$ Th activities from Walter et al. (1997). This procedure does not require an age model of the cores. This ${ }^{230} \mathrm{Th}$ calibration and exclusive use of core-top data reduces the estimates for present accumulation rates from the area of the Polar Front $\left(46-53^{\circ} \mathrm{S}, \mathrm{n}=5\right)$ by a factor of three 
to only $20-35 \mathrm{mmol} \mathrm{m}^{-2} \mathrm{yr}^{-1}$, a mere $1-2 \%$ of primary production (Table 2). As a result of the export of ${ }^{230} \mathrm{Th}$ from the Weddell Sea mentioned above (Walter et al., 2000a), this correction may be somewhat too large, but it is clear that opal accumulation rates have previously been overestimated. It is likely that the lateral supply of sediment is also responsible for part of the diffusive fluxes measured at the sediment-water interface. This would require an additional correction to derive the vertical rain rate to the seafloor. But as the preservation of opal and of Corg increases with rain rate, this correction cannot be expected to be a simple function of the focussing factor. At present we have no way to derive focussing-corrected diagenetic fluxes.

\subsection{4.inverse modelling}

A completely independent estimate of fluxes in the water column is obtained by inverse modelling (Usbeck 1999, 2000; Schlitzer, submitted). In a hydrographical circulation model of the world ocean, the distribution of export production and mineralization is varied until the distribution of nutrients and oxygen, known in great detail, is reproduced as well as possible. At the latitude of the Polar Front Usbeck (1999) arrives at carbon fluxes that agree very well with the other estimates, but the model requires a higher opal export flux and lower opal dissolution in the water column than derived from other estimates (Table 2, Fig. 6).

\subsection{5. export production}

In our estimate of export production during summer we assume that the productive period at the latitude of the Polar Front is about 6 months (based on the seasonal record of the mass flux in the nearby trap deployment PF3, Fischer and Wefer, unpublished, Walter et al., 2000b) and that the export measured in this study during summer is representative for this entire period except for the spring bloom. We thus extrapolate the flux measured during summer over a 160-days period (half a year minus the spring bloom period) and find that $34 \%$ of carbon primary production and $32 \%$ of opal production are exported from the upper $200 \mathrm{~m}$ layer in this 160 -days period. The export measured during the 22-days spring bloom amounted to another $28 \%$ of carbon production and $34 \%$ of opal production. Thus, if we assume one such bloom per year, $45 \%$ for carbon export and $51 \%$ of the opal export occurs in a bloom. The somewhat higher impact of a bloom on the silica export, implied by the high $\mathrm{BSi} /$ Corg ratio observed during the bloom by Quéguiner et al. (1997), is explained by the mass sinking of senescent or empty diatom frustules, in part related to the sexual reproduction phase of Corethron criophilum (Crawford, 1995). A large role of 
blooms in the total silica export was also mentioned by Nelson et al. (1995), and is in line with the results of many trap deployments.

The selection of the depth where the export takes place is critical for the calculated fluxes and composition of exported material. Calculated export fluxes increase with depth as long as ${ }^{234} \mathrm{Th}$ is depleted, i.e. until approximately $200 \mathrm{~m}$ (Table 2). Below this depth, we expect the fluxes to decline with depth as a result of decomposition/dissolution. Organic carbon is decomposed more readily than biogenic silica, which is apparent from a comparison of the composition of suspended material in surface waters with samples of the sediment or the benthic nepheloid layer (Fig. 4c), and also from inverse modelling (Usbeck, 1999 ; Table 2, Fig. 6). It is remarkable that we do not observe this preferential decomposition in the POC/BSi ratio in suspended matter. This ratio does not change from surface waters to waters from 80500m depth (Fig. 4c).

\subsubsection{Discussion of the budget:}

A- Export is not restricted to rapidly developing blooms. On an annual basis, the slow continuous sedimentation produced during summer by the steady plankton community (average chlorophyll-a concentration in the surface mixed layer of the Polar Front region $1 \mu \mathrm{g} / \mathrm{L}$, Hense et al., this issue) is as important as the flux produced by a sudden spring bloom with chlorophyll-a values exceeding $4 \mu \mathrm{g} / \mathrm{L}$. This comparison depends obviously on the assumed duration of the fluxes. As mentioned above, the bloom export may have lasted longer than the 22 days observation period. The assumed 6-month productive period may appear long compared to other trap depoyments in the Southern Ocean. At the AESOPS study, e.g., 84\% of both the POC and the BSi flux was collected in the period Dec. - April, based on data of Honjo et al., (2000). It should be noted, however, that the Polar Front in the SE Atlantic is at approximately $50^{\circ} \mathrm{S}$, compared to $60^{\circ} \mathrm{S}$ during the AESOPS study. But whatever the exact choice of flux duration, this does not affect our conclusion that the annual flux is not only controlled by the bloom-related export. Buesseler et al. (2000) report for their study in the south Pacific sector of the Southern Ocean (US JGOFS AESOPS cruises) a factor of two variation in the POC export flux near the APF. They find a POC flux peak in mid-late January, lagging the onset of the bloom. Their study confirms that carbon and opal export is enhanced late in the blooms but is also significant at other times of the productive season. 
B- We do not know the actual form in which the biogenic material was exported. Small plankton can usually only sink out as larger aggregates, but the rate of aggregate formation was low (Simon, pers. comm.). Dubischar et al. (this issue) demonstrated the high grazing pressure during our study of the abundant small copepod community on smaller plankton particles and zooplankton faecal material. Indeed, since the latter were rare, they must have been efficiently recycled and thus cannot have made a significant contribution to the export flux. Nevertheless, this grazing pressure of the copepod community apparently did not lead to a $100 \%$ efficient recycling food web. Grazing on the small copepod community by larger zooplankton, which exhibits a pronounced diurnal vertical migration (Pollard et al., this issue), and by small fish may have contributed to the export. It may also be that the export is largely in the form of large spiny diatoms, which are not efficiently grazed (Smetacek et al., this issue).

C- The opal export data based on the ${ }^{234} \mathrm{Th}$ depletion fit well into the general picture that $40-60 \%$ of biogenic opal production dissolves within the euphotic zone (Nelson et al., 1995). A similar fraction of organic carbon is decomposed in the surface layer. The other half is exported, supporting the generally efficient export at these latitudes in line with the recent results of Buesseler et al. (2000).

D- Notwithstanding the wealth of data and the reasonable agreement of the various estimates of opal and carbon fluxes against depth (Fig. 6), there is still appreciable uncertainty in the vertical distribution of decomposition rates in the water column, a lack in our understanding also mentioned in the recent review paper by Ragueneau et al. (submitted). Revised estimates of opal accumulation rates support the conclusions of Pondaven et al. (2000) that the opal preservation in this zone is not exceptionally high. But the question whether the opal dissolution takes place in the water column or at the sediment water interface is still linked to the unresolved question what part of the measured diagenetic rates is due to sediment focussing.

E- Although the contribution of the steady summer export to the annual export from the surface ocean is large, we do not know the fate of the fluxes at greater depth. It may well be that the spring bursts lead to a rapid sinking out to the sea floor giving rise to the fluff with viable diatom cells observed by Riaux-Gobin (1997) and the occasional events registrated with sediment traps, whereas the steady summer export with no indication of aggregation (Simon, pers. comm.) may be more exposed to decomposition in the water column.

F- Based on recent evidence that Fe stress promotes the formation of heavily silicified diatoms (Hutchins and Bruland, 1998; Takeda, 1998) and on the observed role of $\mathrm{Fe}$ in the spring bloom (De Baar et al., 1995) we might have expected that the spring 
bloom would have enhanced the export of carbon more than of biogenic silica. This is not observed, as especially in the spring bloom the export was characterized by a high BSi/Corg ratio. Both in the fast-growing spring bloom (Bathmann et al., 1997b, Crawford, 1995) and in a steady-state situation in summer (Smetacek et al., this issue) the diatom community was dominated by large and heavily silicified species. We conclude that Fe stress and grazing pressure select heavily silicified diatoms throughout the year, and that this selection is not remarkably changed by short periods of diminished Fe stress. (Indeed, the spring bloom described here was assumed by Hutchins and Bruland to be Fe stressed based on high $\mathrm{Si} / \mathrm{N}$ uptake ratios).

G- The de-coupling of Si and C export, evident from the high Si/C ratios throughout the year and the high $\mathrm{Si} / \mathrm{C}$ rain ratio on the seafloor, is much stronger in the $\mathrm{SE}$ Atlantic studied here than in the SW Atlantic. In the Scotia Sea, closer to possible terrigenous sources of iron, Si fluxes are similar (Schlüter et al., 1998) but C fluxes are much higher (Schlüter et al., submitted). This strongly supports the possible role of Fe in limiting $\mathrm{C}$ vs $\mathrm{Si}$ export.

\subsection{North-South transects: effects of the subtropical front and of ice cover on the export signal}

Total ${ }^{234} \mathrm{Th}$ activities measured in the surface water on transects from Cape Town to the Antarctic coast (Fig 3) show that the stable low-export situation we observed over the entire sampling period near the Polar Front did not exist at other latitudes. Stronger depletion near the subtropical Front around $42^{\circ} 30^{\prime} \mathrm{S}$ and around $44^{\circ} 30^{\prime} \mathrm{S}$ points at enhanced export rates. This agrees with a very apparent concentration of zooplankton around $44^{\circ} 30$ 'S extending even to $300 \mathrm{~m}$ depth observed with an undulating multisensor device (SeaSoar) by Read et al. (this issue). According to this same SeaSoar survey, the concentrations of chlorophyll-a and of zooplankton are enhanced around the STF until approx. 100m depth, but not to higher levels than around the Polar Front.

A particular situation was observed on our way south at $54^{\circ} \mathrm{S}$, where the SeaSoar survey showed an unusually deep chlorophyll penetration with values exceeding 0.7 $\mu \mathrm{g} / \mathrm{L}$ until about $120 \mathrm{~m}$ depth with a corresponding zooplankton enrichment at the bottom of this layer (Read et al., this issue). A slightly enhanced depletion of ${ }^{234} \mathrm{Th}$ was observed here in the surface water. When the station was reoccupied 12 days later (station 9, Fig. 1,2), the chlorophyll had disappeared to values around $0.4 \mu \mathrm{g} / \mathrm{L}$ between 50 and $100 \mathrm{~m}, 0.3 \mu \mathrm{g} / \mathrm{L}$ at $100 \mathrm{~m}$ and negligible values at $150 \mathrm{~m}$. At $50-100 \mathrm{~m}$ depth ${ }^{234}$ Th was more strongly depleted than anywhere in the Polar Frontal region. 
We interpret this depletion as an export of the deep biogenic material observed on the first SeaSoar transect. In the surface water, total ${ }^{234} \mathrm{Th}$ activity had increased in the intermediate 12 days to ambient values $\left({ }^{234} \mathrm{Th} /{ }^{238} \mathrm{U}\right.$ ratio of 0.77$)$. Ingrowth in the absence of export would have enhanced the activity ratio from 0.649 to 0.751 in this period, indistinguishable from the observed value, but advection may also have been responsible for the observed increase.

Only much further south, dramatic changes occurred in samples which had been drawn when the ship was breaking its way through melting ice. Especially near the northern border of the retreating ice edge, we observed that dense clouds of ice algae were occasionally released. The large excess of ${ }^{234} \mathrm{Th}$ observed in such samples (Fig. 3) implies that ice and/or algae attached to the underside of the ice accumulate this isotope, to release it rapidly upon ice melt. A similar process was postulated by Friedrich (1997) to explain the atypical vertical distribution of ${ }^{210} \mathrm{Po}$ in Antarctic Surface Water. Ice and ice algae may thus have a profound influence on trace element cycling.

\section{Conclusions}

Export in the Southern Ocean is not limited to the sudden development and subsequent collapse of blooms. A diatom community living in approximately steadystate conditions in summer produces an export flux of carbon and opal which is comparable to the export flux following the collapse of a rapidly accumulated spring bloom.

The high BSi/Corg ratio in the export flux in the HNLC Southern Ocean has been explained as a result of iron stress. There is no indication that the temporary alleviation of iron stress by a local $\mathrm{Fe}$ input changes the diatom community to produce a less heavily silicified export flux.

\section{Acknowledgments}

We thank captain and crew of RV Polarstern for their assistance during expedition ANT XIII/2. We are indebted to the oceanographic team for their help in providing the large water samples we needed for the ${ }^{234} \mathrm{Th}$ measurements. The paper has benefitted 
from thoughtful comments of three anonymous reviewers. This is AWI contribution number 1648, SFB 261 contribution number yyy and WHOI contribution number zzz.

\section{References}

Andersson et al. (2000) Particle mediated surface water export: comparison of estimates from ${ }^{238} \mathrm{U}-{ }^{234} \mathrm{Th}$ disequilibria and sediment traps in a continental shelf region. AGU/ASLO Ocean Sciences Meeting, San Antonio.

Bacon M. P. (1984) Glacial to interglacial changes in carbonate and clay sedimentation in the Atlantic Ocean estimated from ${ }^{230} \mathrm{Th}$ measurements. Isotope Geoscience 2, 97-111..

Bacon, M. P., and M. M. Rutgers van der Loeff (1989) Removal of Thorium-234 by scavenging in the bottom nepheloid layer of the ocean. Earth Planet. Sci. Lett., 92, $157-164$.

Baker, E. T. et al. (1988) Field assessment of sediment trap efficiency under varying flow conditions. J. Mar. Res., 46(3), 573-592.

Bakker, D. C. E., H. J. W. De Baar, and U. V. Bathmann (1997) Changes in carbon dioxide in surface waters during spring in the Southern Ocean. Deep-Sea Res. II, 44, 91-127.

Bathmann, U., M. Lucas, and V. Smetacek (1997a) The expeditions Antarktis XIII/1-2 of the Research Vessel "Polarstern" in 1995/1996. Ber. Polarforsch., 221, 136 pp.

Bathmann, U. V., R. Scharek, C. Klaas, C. D. Dubischar, and V. Smetacek (1997b) Spring development of phytoplankton biomass and composition in major water masses of the Atlantic sector of the Southern Ocean. Deep-Sea Res. II, 44, 51-67.

Bennekom, A. J. van, G. W. Berger, S. J. van der Gaast, and R. T. P. de Vries (1988) Primary productivity and the silica cycle in the Southern Ocean. Paleogeogr. Paleoclim. Paleoecol., 67, 19- 30.

Boyle, E. A. (1998) Pumping iron makes thinner diatoms. Nature, 393, 733.

Buesseler (1991) Do upper.ocean sediment traps provide an accurate record of particle flux? Nature 353: 420-423

Buesseler, K. O. (1998) The decoupling of production and particulate export in the surface ocean. Global Biogeochem. Cycles, 12, 297-310. 
Buesseler, K. O., J. A. Andrews, M. C. Hartman, R. Belastock, and F. Chai (1995) Regional estimates of the export flux of particulate organic carbon derived from thorium-234 during the JGOFS EqPac program. Deep-Sea Res. II, 42, 777-804.

Buesseler, K. O., M. P. Bacon, J. K. Cochran, and H. D. Livingston (1992) Carbon and nitrogen export during the JGOFS North Atlantic Bloom Experiment estimated from ${ }^{234} \mathrm{Th}:{ }^{238} \mathrm{U}$ disequilibria. Deep-Sea Res., 39, 1115-1137.

Buesseler K., Ball L., Andrews J., Benitez-Nelson C., Belastock R., Chai F., and Chao Y. (1998) Upper ocean export of particulate organic carbon in the Arabian Sea derived from Thorium-234. Deep-Sea Res. II 45(10/11), 2461-2487.

Buesseler, K. O., D. K. Steinberg, A. F. Michaels, R. J. Johnson, J. E. Andrews, J. R. Valses, and J. F. Price (2000) A comparison of the quantity and composition of material caught in a neutrally buoyant verus surface-tethered sediment trap. Deep-Sea Res. I, 47: 277-294.

Buesseler, K.O., L. Ball, J. Andrews, J.K. Cochran, D.J. Hirschberg, M.P. Bacon, A. Fleer and M. Brzezinski (2000) Upper ocean export of particulate organic carbon and biogenic silica in the Southern Ocean along $170^{\circ} \mathrm{W}$, Deep-Sea Res. II AESOPS special issue, accepted

Burd, A.B., S.B. Moran, and G.A. Jackson (2000) A coupled adsorption-aggregation model of the POC $/^{234}$ Th ratio of marine particles. Deep-Sea Res. I, 47: 103-120.

Coale, K. H., and K. W. Bruland (1987) Oceanic stratified euphotic zone as elucidated by ${ }^{234} \mathrm{Th}:{ }^{238} \mathrm{U}$ disequilibria. Limnol. Oceanogr., 23, 189-200.

Crawford, R. M. (1995) The role of sex in the sedimentation of a marine diatom bloom. Limnol. Oceanogr., 40, 200-204.

Dafner, E. V., and N. V. Mordasova (1994) Influence of Biotic Factors on the Hydrochemical Structure of Surface Water in the Polar Frontal Zone of the Atlantic Antarctic. Mar. Chem., 45, 137-148.

De Baar, H. J. W., and P. W. Boyd (in press) The role of Iron in Plankton ecology and carbon dioxide transfer of the global oceans. in The dynamic ocean carbon cycle. A midterm synthesis of the Joint Global FLux Study., edited by H. W. Ducklow, J. G. Field, and R. B. Hanson, Cambridge University Press, Cambridge. 
De Baar, H. J. W., J. T. M. De Jong, D. C. E. Bakker, B. M. Löscher, C. Veth, U. Bathmann, and V. Smetacek (1995) Importance of iron for plankton blooms and carbon dioxide drawdown in the Southern Ocean. Nature, 373, 412-415.

Dubischar, C.D., R.M. Lopes and U.V. Bathmann (2000) High summer abundances of small pelagic copepods at the Antarctic Polar Front - implications for ecosystem dynamics. Deep-Sea Res. II, this issue, submitted.

Fischer, G., D. Fuetterer, R. Gersonde, S. Honjo, D. Osterman, and G. Wefer (1988) Seasonal variability of particle flux in the Weddell Sea and its relation to ice cover. Nature, 335, 426-428.

Francois R., Bacon M. P., Altabet M. A., and Labeyrie L. D. (1993) Glacial/Interglacial changes in sediment rain rate in the SW Indian sector of subantarctic waters as recorded by ${ }^{230} \mathrm{Th},{ }^{231} \mathrm{~Pa}, \mathrm{U}$, and $\delta^{15} \mathrm{~N}$. Paleoceanography $8(5), 611-629$.

Frank M. (1996) Reconstruction of late Quaternary environmental conditions applying the natural radionuclides ${ }^{230} \mathrm{Th},{ }^{10} \mathrm{Be},{ }^{231} \mathrm{~Pa}$ and ${ }^{238} \mathrm{U}$ : A study of deep-sea sediments from the eastern sector of the Antarctic Circumpolar Current System. Ber. Polarforsch. 186, 1-136.

Frank M., Gersonde R., and Mangini A. (1999) Sediment redistribution, ${ }^{230} \mathrm{Th}_{\mathrm{ex}}$ normalization and implications for the reconstruction of particle flux and export paleoproducitivity. In Use of proxies in paleoceanography (ed. G. Fischer and G. Wefer), pp. 409-426. Springer, Berlin.

Friedrich, J. (1997) Polonium-210 und Blei-210 im Südpolarmeer: Natürliche Tracer für biologische und hydrographische Prozesse im Oberflächenwasser des Antarktischen Zirkumpolarstroms und des Weddellmeeres. Ber. Polarforsch., 235, 1-155.

Friedrich, J. and Rutgers van der Loeff, M.M. (submitted) A two-tracer $\left({ }^{210} \mathrm{Po}-{ }^{234} \mathrm{Th}\right)$ approach to distinguish organic carbon and biogenic silica export flux in the Antarctic Circumpolar Current, Deep-Sea Research I, submitted.

Gust, G., A. F. Michaels, R. Johnson, W. G. Deuser, and W. Bowles (1994) Mooring line motions and sediment trap hydrodynamics: in situ intercomparison of three common deployment designs. Deep-Sea Res. I, 41, 831-857.

Hartman, M. C., and K. O. Buesseler (1994) Adsorbers for in-situ collection and at-sea gamma analysis of dissolved Thorium-234 in seawater, WHOI, Woods Hole, 
Hense, I. et al., this issue

Honeyman, B. D., and P. H. Santschi (1989) A Brownian-pumping model for oceanic trace metal scavenging: Evidence from Th isotopes. J. Mar. Res., 47, 951-992.

Honjo, S., Francois, R., Manganini, S., Dymond, J., Collier, R., 2000. Export fluxes in the western Pacific sector of the Southern Ocean along 170W. In press: Deep-Sea Research II, First Special Issue, AESOPS volume.

Hutchins, D. A., and K. W. Bruland (1998) Iron-limited diatom growth and Si:N uptake ratios in a coastal upwelling regime. Nature, 393, 561-564.

Jochem, F.J., S. Mathot and B. Quéguiner (1995) Size-fractionated primary production in the open Southern Ocean in austral spring. Polar Biology, 15, 381-392.

Johnson, B.D. and Wangerski, P.J. (1985) Seawater filtration : particle flow and impaction considerations. Limnol. Oceanogr. 30, 966-971.

Ku, T. L., and M. C. Lin (1976) 226Ra distribution in the Antarctic Ocean. Earth Planet. Sci. Lett., 32, 236.

Kumar, N., R. F. Anderson, R. A. Mortlock, P. N. Froelich, P. Kubik, B. Dittrich-Hannen, and M. Suter (1995) Increased biological productivity and export production in the glacial Southern Ocean. Nature, 378, 675-680.

Lee, T., E. Barg, D. Lal, and F. Azam (1993). Bacterial scavenging of ${ }^{234}$ Th in surface ocean waters. Marine Ecology Progress Series, 96, 109-116.

Leynaert, A., D. M. Nelson, B. Quéguiner, and P. Tréguer (1993) The silica cycle in the Antarctic Ocean: is the Weddell Sea atypical? Mar. Ecol. Progr. Ser., 96, 1-15.

Lisitzin, A. P. (1996) Oceanic Sedimentation: Lithology and Geochemistry, AGU, Washington.

Lutjeharms, J. R. E., N. M. Walters, and B. R. Allanson (1985) Oceanic Frontal Systems and biological enhancement. in Antarctic nutrient cycles and food webs., edited by W. R. Siegfried, P. R. Condy, and R. M. Laws, pp. 11-21, Springer, Berlin.

Menzel, D.W. (1966) Bubbling of seawater and the production of organic particles : a reevaluation. Deep-Sea Res. 13, 963-966.

Moore, W. S. (1984) Radium isotope measurements using germanium detectors. Nuclear Instruments and Methods in Physics Research, 223, 407-411. 
Moore, W. S., R. M. Key, and J. L. Sarmiento (1985) Techniques for precise mapping of ${ }^{226} \mathrm{Ra}$ and ${ }^{228} \mathrm{Ra}$ in the ocean. J. Geophys. Res., 90, 6983-6994.

Moran, S.B., M.A. Charette, S.M. Pike, and C.A. Wicklund (1999) Differences in seawater particulate organic carbon concentration in samples collected using small- and largevolume methods: the importance of DOC adsorption to the filter blank. Mar. Chem. 67: $33-42$.

Mueller, P. J., and R. Schneider (1993) An Automated Leaching method for the Determination of Opal in Sediments and Particulate Matter. Deep-Sea Res., 40, 425444.

Murray, J. W., J. N. Downs, S. Strom, C. -L Wei, and H. W. Jannasch (1989) Nutrient assimilation, export production and ${ }^{234} \mathrm{Th}$ scavenging in the eastern equatorial Pacific. Deep-Sea Res., 36, 1471-1489.

Murray, J.W., J. Young, J. Newton, J. Dunne, T. Chapin, B. Paul, and J.J. McCarthy (1996) Export flux of particulate organic carbon from the central equatorial Pacific determined using a combined drifting trap $-{ }^{234}$ Th approach. Deep-Sea Res. II, 43, 1095-1132.

Nelson, D. M., P. Tréguer, M. A. Brzezinski, Leynaert, and B. Quéguiner (1995) Production and dissolution of biogenic silica in the ocean: Revised global estimates, comparison with regional data and relationship to biogenic sedimentation. Global Biogeochem. Cycles, 9, 359-372.

Pondaven P., Ragueneau O., Tréguer P., Hauvespre A., Dezileau L., and Reyss J. L. (2000) Resolving the "opal paradox" in the Southern Ocean. Nature 405, 168-172.

Quéguiner, B. (1996) EOS, supplement AGU ocean sciences meeting,

Quéguiner, B., P. Tréguer, I. Peeken, and R. Scharek (1997) Biogeochemical dynamics and the silicon cycle in the Atlantic sector of the Southern Ocean during austral spring 1992. Deep-Sea Res. II, 44, 69-89.

Rabouille, C., J. -F Gaillard, P. Tréguer, and M. -A Vincendeau (1997) Biogenic-silica recycling in surficial sediments across the Polar Front of the Southern Ocean (Indian Sector). Deep-Sea Res. II, 44, 1151-1176. 
Ragueneau, O., P. Tréguer, R. F. Anderson, M. A. Brzezinski, D. J. DeMaster, R. C. Dugdale, J. Dymond, G. Fischer, R. Francois, C. Heinze, A. Leynaert, A. MaierReimer, V. Martin-Jézéquel, D. M. Nelson, and B. Quéguiner Understanding the Si cycle in the modern ocean: a pre-requisite for the use of biogenic opal as a paleoproductivity proxy. Global and Planetary Change, submitted.

Read, J. F., R. T. Pollard, and U. Bathmann (this issue) Physical and biological patchiness of an upper ocean transect from South Africa to the ice edge at the Greenwich Meridian. Deep-Sea Res. II, submitted.

Riaux-Gobin, C., P. E. Hargraves, J. Neveux, Oriol. L., and G. Vétion (1997) Microphyte pigments and resting spores at the water-sediment interface in the Subantarctic deep sea (Indian sector of the Southern Ocean). Deep-Sea Res. II, 44, 1033-1051.

Rutgers van der Loeff, M. M., and G. W. Berger (1991) Scavenging and particle flux: seasonal and regional variations in the southern ocean (Atlantic sector). Mar. Chem., 35, 553-568.

Rutgers van der Loeff, M. M., J. Friedrich, and U. V. Bathmann (1997) Carbon export during the spring bloom at the southern Polar Front, determined with the natural tracer ${ }^{234} \mathrm{Th}$. Deep-Sea Res. II, 44, 457-478.

Rutgers van der Loeff, M. M., and W. S. Moore (1999) Determination of natural radioactive tracers. Chapter 13. in Methods of Seawater Analysis, edited by K. Grasshoff, M. Ehrhardt, and K. Kremling, Verlag Chemie, Weinheim, pp. 365-397

Sarmiento, J. L., and J. C. Orr (1991) Three-dimensional model simulations of the impact of Southern Ocean nutrient depletion on atmospheric $\mathrm{CO}_{2}$ and ocean chemistry. Limnol. Oceanogr., 36, 1928-1950.

Schlitzer, R. (2000) Carbon export fluxes in the Southern Ocean: results from inverse modeling and comparison with satellite based estimates, Deep-Sea Res. II, submitted.

Schlüter, M., M. M. Rutgers van der Loeff, and O. Holby Regional differences in organic carbon flux to the seafloor of the southern South Atlantic, submitted.

Schlüter, M., M. M. Rutgers van der Loeff, O. Holby, and G. Kuhn (1998) Silica cycle in surface sediments of the South Atlantic. Deep-Sea Res., 45, 1085-1109. 
Scholten, J.C., J. Fietzke, S. Vogler, M.M. Rutgers van der Loeff, A. Mangini, W. Koeve, P. Stoffers, A. Antia, S. Neuer, J. Waniek. Trapping efficiencies of sediment traps from the deep waster north Atlantic: The ${ }^{230}$ Th calibration. Deep-Sea Research II. JGOFS North Atlantic Synthesis, in press

Smetacek, V., R. Scharek, and E. -M Nöthig (1990) Seasonal and regional variation in the pelagial and its relationship to the life history cycle of krill. in Antarctic ecosystems: Ecological change and conservation, edited by K. R. Kerry, and G. Hempel, pp. 103114 , Springer, Berlin.

Strickland, J. D. H., and T. R. Parsons (1972) A Practical Handbook of Seawater Analysis, 2nd edition. Bull.Fish.Res.Board Canada, 167, 310pp.

Takeda, S. (1998) Influence of Iron availablitity on nutrient consumption ratio of diatoms in oceanic waters. Nature, 393, 774-777.

Tréguer P., and G. Jaques (1992) Dynamics of Nutrients and Phytoplankton, and Fluxes of Carbon, Nitrogen and Silicon in the Antarctic Ocean. Polar Biology, 12, 149-162.

Tréguer, P., D. M. Nelson, A. J. van Bennekom, D. J. DeMaster, A. Leynaert, and B. Quéguiner (1995) The silica balance in the World Ocean: a reestimate. Science, 268, 375-379.

Tréguer, P., and A. J. van Bennekom (1991) The annual production of biogenic silica in the Antarctic Ocean. Mar. Chem., 35, 477-487.

Usbeck R.(1999) Modeling of marine biogeochemical cycles with an emphasis on vertical particle fluxes. Reports on Polar Research, 332, 105 pp. , see http://www.awibremerhaven.de/GEO/Publ/PhDs.html

Usbeck, R., R. Schlitzer and G. Fischer (2000) Particle fluxes in the ocean: Comparison of sediment trap data with results from inverse modeling, submitted to Global Biogeochemical Cycles.

Veth, C., I. Peeken, and R. Scharek (1997) Physical anatomy of fronts and surface waters in the ACC near the $6^{\circ} \mathrm{W}$ meridian during austral spring 1992. Deep-Sea Res. II, 44, 23 49.

Walter, H.J., M.M. Rutgers van der Loeff and H. Höltzen, (1997) Enhanced scavenging of ${ }^{231} \mathrm{~Pa}$ relative to ${ }^{230} \mathrm{Th}$ in the South Atlantic south of the Polar Front: Implications for 
the use of the ${ }^{231} \mathrm{~Pa} /{ }^{230} \mathrm{Th}$ ratio as a paleoproductivity proxy, Earth Planet. Sci. Lett. 149, 85-100.

Walter, H. J., M. M. Rutgers van der Loeff, H. Hoeltzen, U. Bathmann (2000a) Reduced scavenging of ${ }^{230} \mathrm{Th}$ in the Weddell Sea: Implications for paleoceanographic reconstructions in the South Atlantic. Deep-Sea Research I, 47, 1369-1387.

Walter, H. J., W. Geibert, M. M. Rutgers van der Loeff, G. Fischer and U. Bathmann (2000b) Shallow vs. deep-water scavenging of ${ }^{231} \mathrm{~Pa}$ and ${ }^{230} \mathrm{Th}$ in radionuclide enriched waters of the Atlantic Sector of the Southern Ocean. Deep-Sea Research, I, in press.

Wefer, G., and G. Fischer (1991) Annual primary production and export flux in the Southern Ocean from sediment trap data. Mar. Chem., 35, 597-614.

Wefer, G., G. Fischer, D. K. Fütterer, R. Gersonde, S. Honjo, and D. Osterman (1990) Particle sedimentation and productivity in Antarctic waters of the Atlantic Sector. in Geological History of the Polar Oceans: Arctic versus Antarctic., edited by U. Bleil, and J. Thiede, pp. 363-379, Kluwer.

Wefer, G., G. Fischer, D. Fütterer, and R. Gersonde (1988) Seasonal particle flux in the Bransfield Strait, Antarctica. Deep-Sea Res., 35, 891-898.

Whitworth, T., and W. D. Nowlin (1987) Water masses and currents of the Southern Ocean at the Greenwich meridian. J. Geophys. Res., 92, 6462-6476.

Yu, E. -F, R. Francois, M. P. Bacon, S. Honjo, A. P. Fleer, S. J. Manganini, M. M. Rutgers van der Loeff, and V. Ittekot. Trapping efficiency of bottom-tethered sediment traps estimated from the intercepted fluxes of ${ }^{230} \mathrm{Th}$ and ${ }^{231} \mathrm{~Pa}$. Submitted to Deep-Sea Res. $I$, submitted. 
Tables

Table 1. Comparison of total-234Th/238U ratios in surface waters from the Polar Front Box using in-line filtration (ILF) and discrete volume filtration (DF)

\begin{tabular}{lcc}
\hline station & ILF & DF \\
\hline 11 & 0,86 & 0,79 \\
34 & 0,89 & 0,83 \\
35 & 0,89 & 0,80 \\
38 & 0,93 & 0,77 \\
\hline average 4 statiol & $0,89 \pm 0,03 \quad(n=4)$ & $0,80 \pm 0,03 \quad(n=4)$ \\
all data PF box & $0,81 \pm 0,08 \quad(n=15)$ & $0,81 \pm 0,04 \quad(n=46)$ \\
\hline
\end{tabular}

Table 1. Comparison of total- ${ }^{234} \mathrm{Th} / 238 \mathrm{U}$ ratios in surface waters from the Polar Front Box using in-line filtration (ILF) and discrete volume filtration (DF). 
Table 2. POC and BSi fluxes in Polar Front region during spring and summer, and yearly estimates in comparison with literature estimates on production, export, sedimentation and burial fluxes.

\begin{tabular}{|c|c|c|c|c|c|c|c|c|c|c|c|c|c|}
\hline \multirow{3}{*}{\multicolumn{2}{|c|}{$\begin{array}{r}\text { depth } \\
\mathrm{m} \\
\end{array}$}} & \multirow{3}{*}{ ref. } & \multirow{3}{*}{$\begin{array}{c}\text { Th-234 } \\
\\
d p m \\
m^{-2} d^{-1}\end{array}$} & \multirow{3}{*}{$\begin{array}{l}\text { productive } \\
\text { period } \\
\text { days }\end{array}$} & \multicolumn{4}{|c|}{ organic Carbon } & \multicolumn{2}{|c|}{ Biogenic } & \multicolumn{2}{|c|}{ Silica } & \multirow{3}{*}{$\begin{array}{l}\text { BSi/Corg } \\
\text { molar ratio }\end{array}$} \\
\hline & & & & & \multirow{2}{*}{$\begin{array}{l}\mathrm{mmol} \\
\mathrm{m}^{-2} \mathrm{~d}^{-1}\end{array}$} & \multirow{2}{*}{$\begin{array}{c}\mathrm{mmol} \\
\mathrm{m}^{-2} \mathrm{yr}^{-1}\end{array}$} & \multirow{2}{*}{$\begin{array}{c}\text { part in } \\
\text { bloom } \\
\%\end{array}$} & \multirow{2}{*}{$\begin{array}{c}\text { part of } \\
\text { annual PP } \\
\% \\
\end{array}$} & \multirow{2}{*}{$\begin{array}{c}\mathrm{mmol} \\
\mathrm{m}^{-2} \mathrm{~d}^{-1} \\
\end{array}$} & \multirow{2}{*}{$\begin{array}{l}\mathrm{mmol} \\
\mathrm{m}^{-2} \mathrm{yr}^{-1}\end{array}$} & \multicolumn{2}{|c|}{$\begin{array}{l}\text { part in part of } \\
\text { bloom annual PP }\end{array}$} & \\
\hline & & & & & & & & & & & $\%$ & $\%$ & \\
\hline \multicolumn{14}{|c|}{ Primary production } \\
\hline & & 1) & & & & 5333 & & 100 & & 1600 & & 100 & 0,30 \\
\hline \multicolumn{14}{|c|}{ Export } \\
\hline & 100 & & 865 & 160 & 8,78 & 1406 & & 26 & 2,51 & 401 & & 25 & 0,29 \\
\hline & 133 & & 1014 & 160 & 10,31 & 1649 & & 31 & 2,94 & 471 & & 29 & 0,29 \\
\hline & 200 & & 1115 & 160 & 11,33 & 1812 & & 34 & 3,23 & 517 & & 32 & 0,29 \\
\hline \multicolumn{14}{|l|}{ bloom (ANT X/6) } \\
\hline summer export & 200 & & 3200 & 22 & 66,88 & 1471 & 45 & 28 & 24,58 & 541 & 51 & 34 & 0,37 \\
\hline+1 bloom & 200 & & & & & 3284 & & 62 & & 1058 & & 66 & 0,32 \\
\hline \multicolumn{14}{|c|}{ inverse modelling } \\
\hline & 133 & & & & & 2597 & & 49 & & 1871 & & 117 & 0,72 \\
\hline & 200 & & & & & 1560 & & 29 & & 1870 & & 117 & 1,20 \\
\hline & 700 & & & & & 326 & & 6,1 & & 1868 & & 117 & 5,73 \\
\hline & 4000 & 4) & & & & 37 & & 0,7 & & 1865 & & 117 & 50,57 \\
\hline \multicolumn{14}{|c|}{ Sediment trap (Th-230 corrected) } \\
\hline PF1 & 700 & $5), 7)$ & & & & 605 & & 11,3 & & 658 & & 41 & 1,09 \\
\hline PF3 & 614 & 6),7) & & (bloom Jar & +March) & 428 & 34 & 8,0 & & 648 & 37 & 41 & 1,52 \\
\hline PF3 & 3196 & 6),7) & & & & 778 & & 14,6 & & 464 & & 29 & 0,60 \\
\hline \multicolumn{14}{|c|}{ Decomposition in surface sediment } \\
\hline $\begin{array}{l}\text { pore water data } \\
\text { (median values) }\end{array}$ & 4000 & 8),9), 10) & & & & 130 & & 2,4 & & 600 & & 38 & 4,62 \\
\hline \multicolumn{14}{|c|}{ Sediment accumulation (Th-230 corrected) } \\
\hline \multirow[t]{2}{*}{ core-top data } & 4000 & $11), 12)$ & & from & & 2 & & 0,0 & & 20 & & 1 & 12,00 \\
\hline & & & & to & & 3 & & 0,1 & & 35 & & 2 & 12,00 \\
\hline \multicolumn{14}{|c|}{ references: } \\
\hline \multirow{2}{*}{\multicolumn{5}{|c|}{$\begin{array}{l}\text { 1) Quéguiner et al., } 1996,1997 \\
\text { 2) this work }\end{array}$}} & \multicolumn{4}{|c|}{ 7) Walter et al., $2000 \mathrm{~b}$} & & & & & \\
\hline & & & & & 8) van $\mathrm{Be}$ & nnekom et & t al., 19 & & & & & & \\
\hline 3) Rutgers van der LC & oeff et $a$ & al., 1997 & and this wor & & 9) Schlüte & r et al., 19 & 998 & & & & & & \\
\hline 4) Usbeck, 1999 & & & & & 10) Schlü & ter et al., s & submitte & & & & & & \\
\hline 5) Wefer and Fischer & r, 1991 & & & & 11) $230 \mathrm{Tr}$ & data from & n Walter & r et al., 1997 & & & & & \\
\hline 6) Fischer and Wefer & r, unpul & & & & 12) Schlü & ter, pers. & Comm. & & & & & & \\
\hline
\end{tabular}

Table 2. POC and BSi fluxes in the Polar Front region in the SE Atlantic during spring bloom and summer, and yearly estimates in comparison with literature estimates on primary production, export, sedimentation and burial fluxes. 


\section{Figure legends}

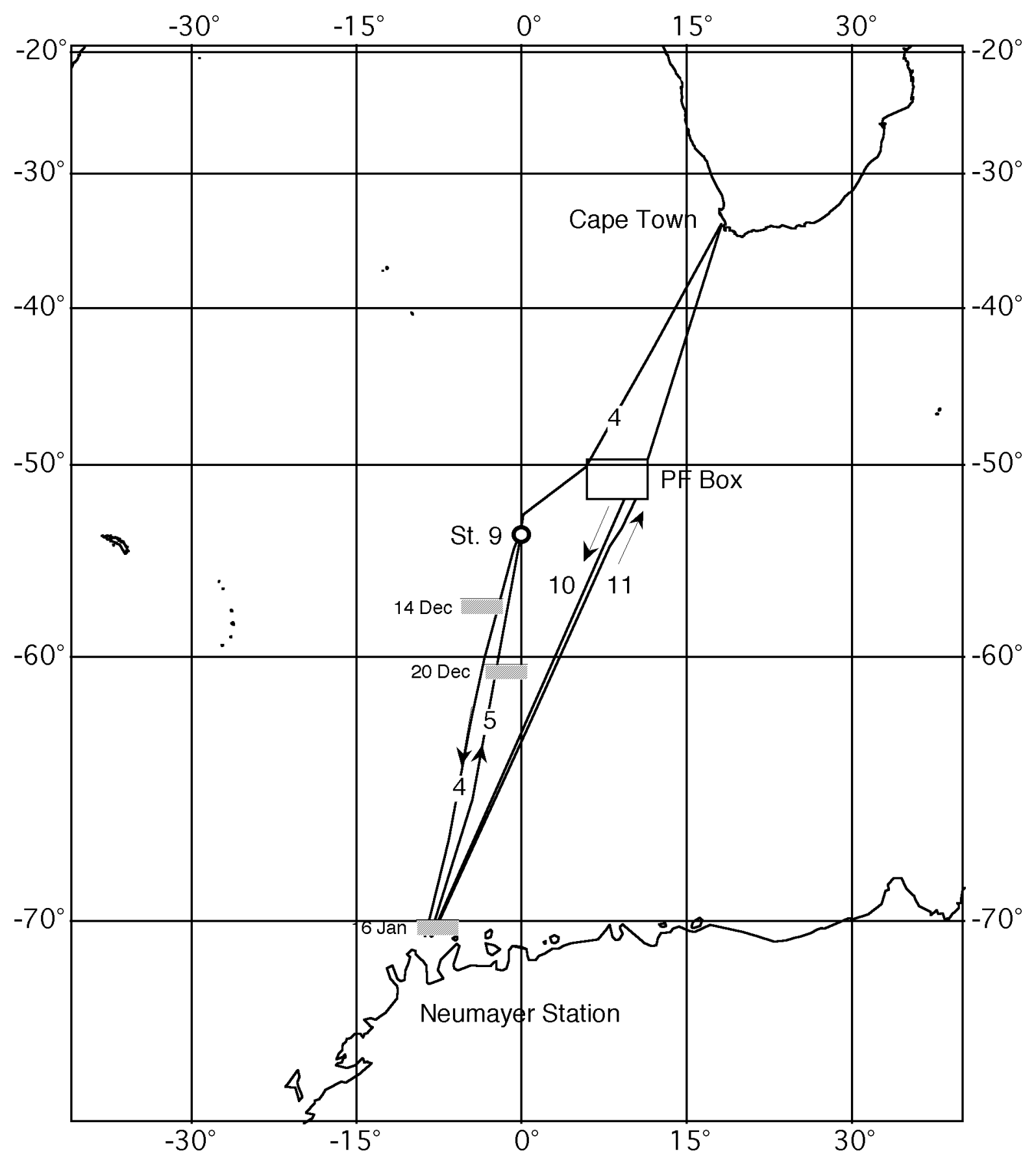

Fig. 1 Cruise track with numbers of transects as indicated in Fig. 3, the approximate position where the transects crossed the ice edge (hatched), the position of Station 9, and the intensively studied Box near the Polar Front. 


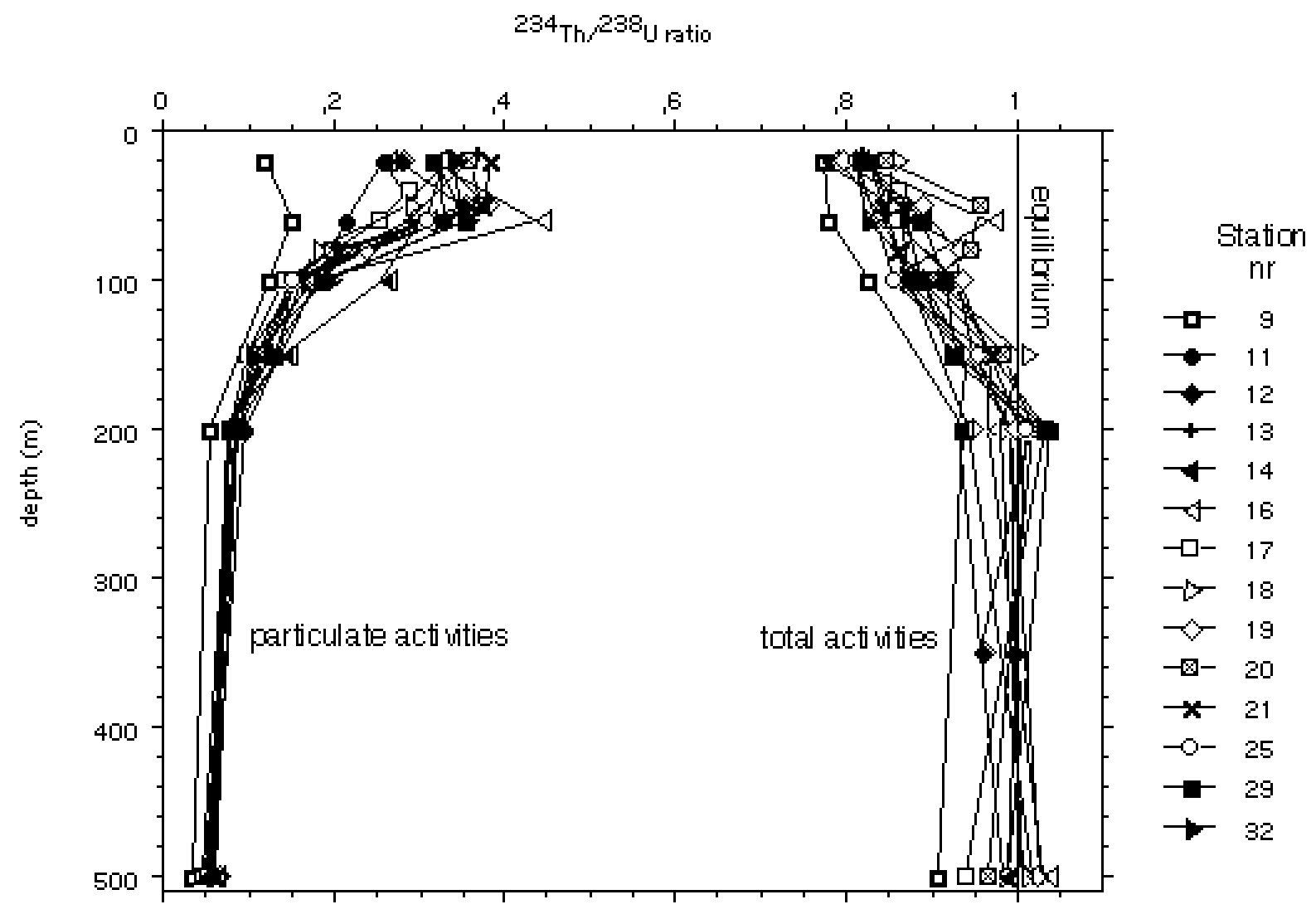

Fig. 2. Depth profiles of particulate (left) and total (right) ${ }^{234} \mathrm{Th}$ activities, presented as ratio to the activity of the parent nuclide ${ }^{238} \mathrm{U}(1=$ secular equilibrium). 


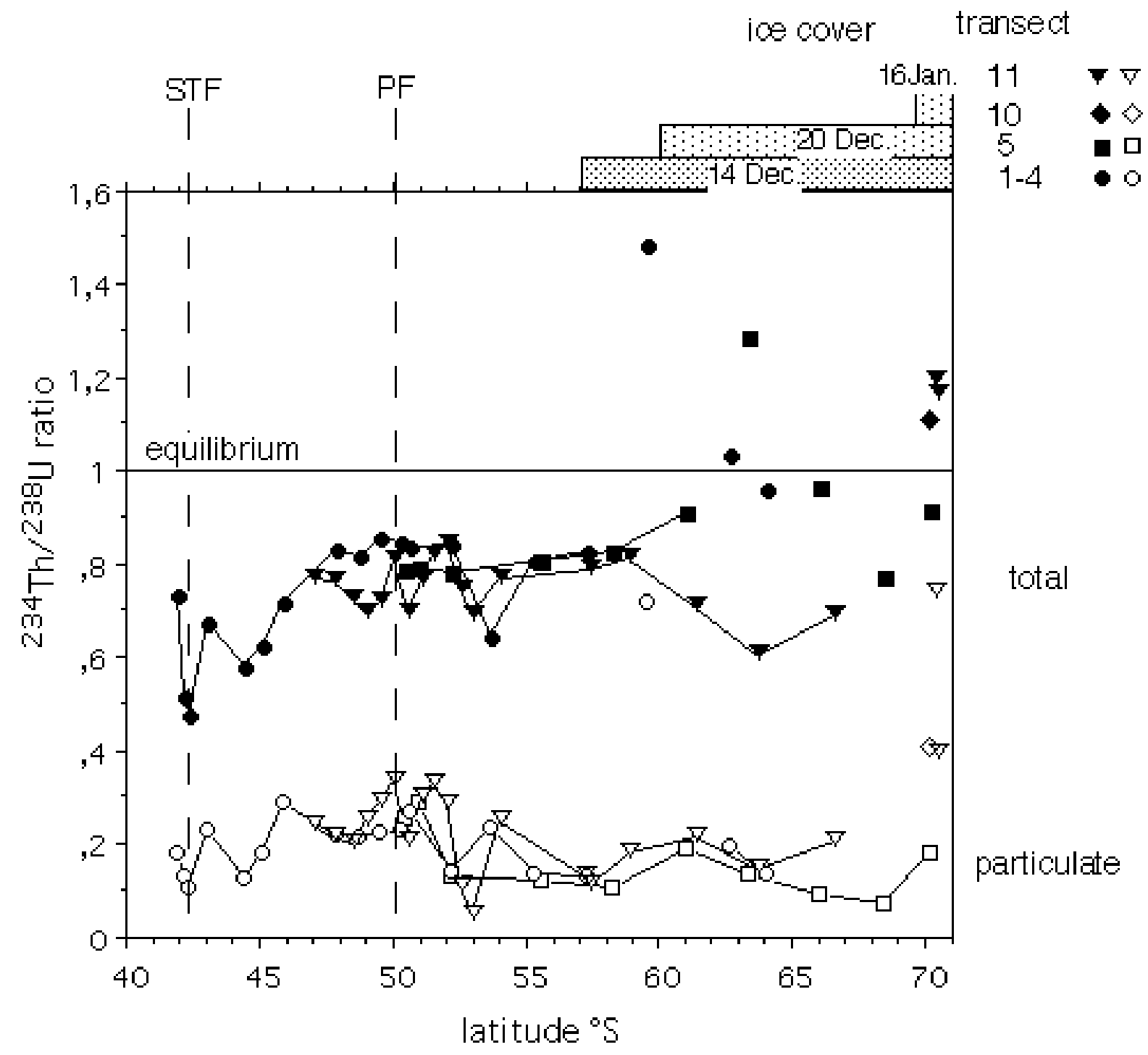

Fig. 3. Particulate (open symbols) and total (closed symbols) ${ }^{234} \mathrm{Th}$ in surface water, expressed as a ratio to ${ }^{238} \mathrm{U}$, over the various N-S transects, showing the depletion of total ${ }^{234} \mathrm{Th}$ relative to ${ }^{238} \mathrm{U}$ near the Subtropical Front (STF), at $44: 30^{\circ} \mathrm{S}$ and at $54^{\circ} \mathrm{S}$ (Station 9) compared with the moderate depletion in the Polar Front (PF) Box. The excess activities in the south are ascribed to accumulation on ice algae. 

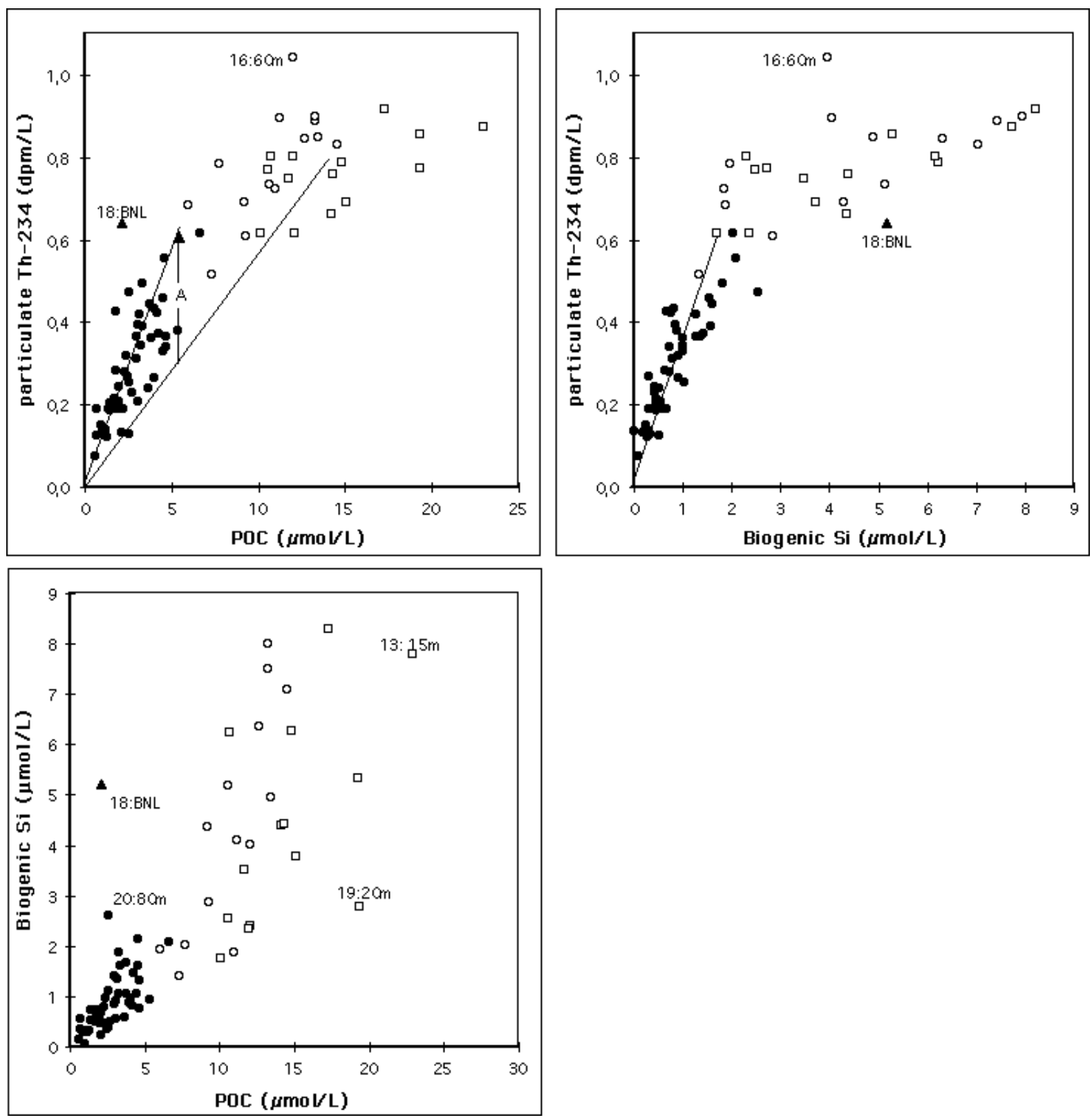

Fig. 4. Particulate ${ }^{234} \mathrm{Th}(\mathrm{dpm} / \mathrm{L})$ as a function of POC (particulate organic carbon, a) and biogenic silica (BSi, b) and BSi versus POC (c) in all samples from the Polar Front area $\left(49^{\circ} 30^{\prime}\right.$ to $\left.51^{\circ} 30^{\prime} \mathrm{S}\right)$ where BSi was measured, distinguishing samples from the surface water (open squares), from 20-60 m depth (open circles) and from below $80 \mathrm{~m}$ (closed symbols) with regression lines through the origin (eqs. 1 and 2). One sample from the benthic nepheloid layer (BNL, triangle) at station 18 depicts the influence of resuspended surface sediments. 

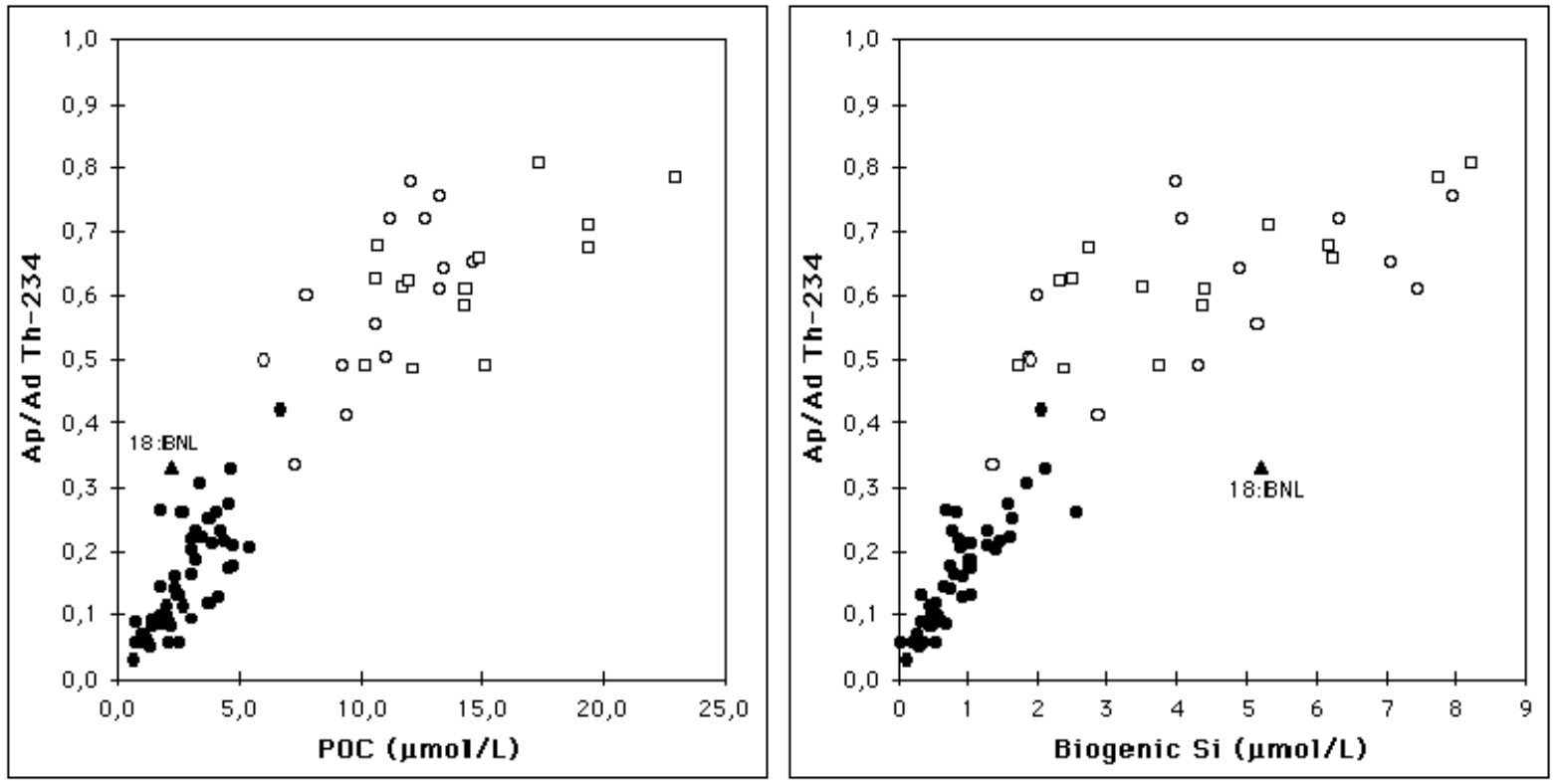

Fig. 5. The ratio of particulate to dissolved ${ }^{234} \mathrm{Th}$ activity as a function of POC (a) and BSi (b). Symbols as in Fig. 4. 

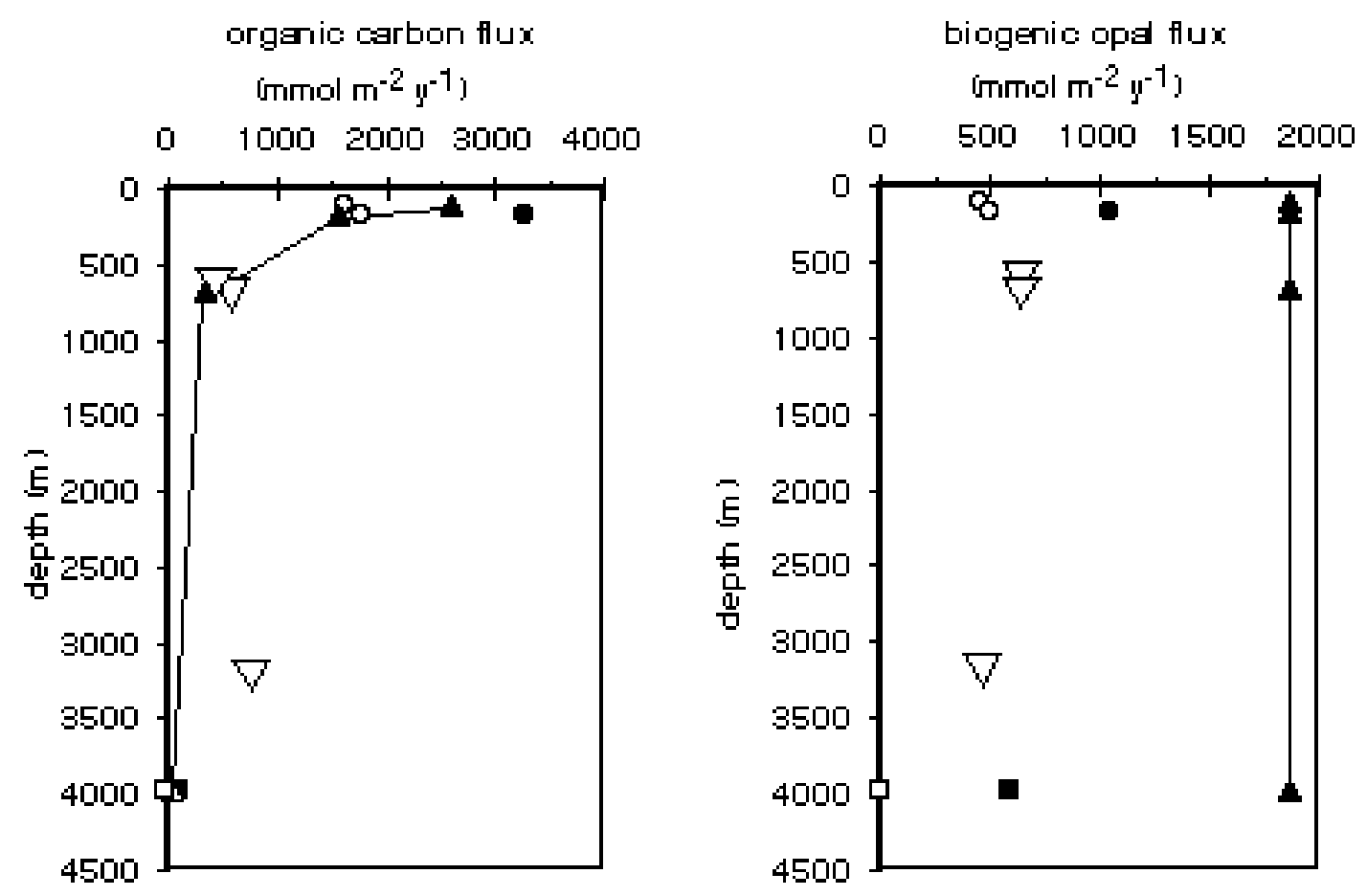

fig. 6

Fig. 6. Fluxes of organic carbon (a) and opal (b) as function of water depth around the Polar Front in the SE Atlantic according to data summarized in Table 2, distinguishing the total export flux at $200 \mathrm{~m}$ (filled circles), the export flux in summer (open circles), sediment trap fluxes (open triangles), results from inverse modelling (filled triangles connected by line), rain rate to the sediment (filled squares) and sediment accumulation rate (open squares). 